\title{
Drought impact on carbon and water cycling in a Mediterranean Quercus suber L. woodland during the extreme drought event in 2012
}

\author{
A. Piayda ${ }^{1}$, M. Dubbert ${ }^{2}$, C. Rebmann ${ }^{1}$, O. Kolle ${ }^{3}$, F. Costa e Silva ${ }^{4}$, A. Correia ${ }^{4}$, J. S. Pereira ${ }^{4}$, C. Werner ${ }^{2}$, and \\ M. Cuntz ${ }^{1}$ \\ ${ }^{1}$ Department Computational Hydrosystems, UFZ Helmholtz Centre for Environmental Research, Permoserstr. 15, \\ 04318 Leipzig, Germany \\ ${ }^{2}$ Agroecosystem Research, BayCEER, University of Bayreuth, Universitätsstr. 30, 95447 Bayreuth, Germany \\ ${ }^{3}$ Field Experiments \& Instrumentation, Max Planck Institute for Biogeochemistry, Hans-Knöll-Str. 10, 07745 Jena, Germany \\ ${ }^{4}$ Department of Forestry, Instituto Superior de Agronomia, Technical University of Lisbon, Tapada da Ajuda, \\ 1349-017 Lisbon, Portugal
}

Correspondence to: A. Piayda (arndt.piayda@ufz.de)

Received: 17 June 2014 - Published in Biogeosciences Discuss.: 3 July 2014

Revised: 29 September 2014 - Accepted: 12 November 2014 - Published: 16 December 2014

\begin{abstract}
Savannah-type ecosystems account for 26-30\% of global gross primary productivity GPP, with water being one of the major driving factors. In Europe, savannah-type woodlands cover an area of about 1.5 million ha. Here, the recent past has shown a significant decrease in precipitation $P$ in winter and spring as well as a decrease in total annual precipitation. Strong effects on local water balance and carbon sink strength have thus been reported due to changes in precipitation regime.

The objective of this study is to quantify the impact of the extreme drought event in 2012 on the water balance, gross primary productivity and carbon sink strength of a typical Portuguese cork-oak woodland (montado) compared to the wet year of 2011. Physiological responses of the dominant tree species Quercus suber (L.) are disentangled employing combined photosynthesis and stomatal conductance modelling.

Precipitation effectiveness ET $/ P$ increased from $86 \%$ in 2011 to $122 \%$ in the 2012 dry year due to deep soil or groundwater access of the $Q$. suber trees leaving no water for groundwater replenishment. Understorey and overstorey GPP were strongly reduced, by 53 and $28 \%$, respectively, in 2012 compared to 2011, due to the late onset of the autumn rains in 2011 and an additional severe winter/spring drought. However, the ecosystem was still a carbon sink in
\end{abstract}

both years, but with a $38 \%$ reduced sink strength under extreme drought in 2012 compared to 2011. The combined photosynthesis-stomatal conductance model yielded the best results if it was allowed to adjust photosynthetic and stomatal parameters simultaneously. If stomatal response was modelled with the Leuning approach, which allows for a different sensitivity to vapour pressure deficit, the stomatal model parameters were highly coupled. A change in either of the parameters needed to be compensated by the other to guarantee a stable sensitivity of stomatal conductance to assimilation, independent of variations in vapour pressure deficit. The $Q$. suber trees showed a $37 \%$ reduced stomatal conductance during the drought period of 2012 compared to 2011 , due to water supply limitations. In response to reduced leafinternal $\mathrm{CO}_{2}$ availability, the trees strongly reduced the apparent maximum carboxylation rate by $43 \%$ in 2012 compared to 2011. Unexpectedly, the optimum temperature $T_{\mathrm{opt}}$ of the maximum electron transport rate decreased during the drought period, enhancing the susceptibility of the trees to high temperature stress during the summer.

Our results suggest that, if the trend of decreasing annual precipitation and changed precipitation patterns on the Iberian Peninsula continues, sustained effects on local groundwater reservoirs, understorey species composition and tree mortality have to be expected in the long term. 
To model the effect of drought on the montado ecosystem successfully, variable apparent maximum carboxylation rate $V_{\mathrm{c}, \max }$, stomatal conductance parameter $m$ and vapour pressure deficit sensitivity parameter $D_{0}$ need to be incorporated into photosynthesis-stomatal conductance modelling.

\section{Introduction}

One of the typical semi-arid ecosystems in Europe is a savannah-type woodland (montado), consisting of a sparse overstorey tree layer and a herbaceous understorey layer. During the biomass peak of the herbaceous plants in spring, the understorey layer can provide a large contribution to the whole ecosystem water and carbon balance and, thus, can play a significant role in the annual carbon and water budgets (Unger et al., 2009; Paco et al., 2009; Dubbert et al., 2014b). However, each layer responds differently to changes in precipitation, depending on its life form (chamaephyte or therophyte) and access to different water reservoirs throughout the year (Paco et al., 2009), including deep soil or groundwater (David et al., 2004).

Montado ecosystems (span.: dehesa) cover an area of about 1.5 million ha in Europe (Bugalho et al., 2011) and contribute together with savannah-type ecosystems on other continents about $30 \%$ to global gross primary productivity GPP (Beer et al., 2010; Grace et al., 2006). The major driving factor of GPP in montado ecosystems is water (Vargas et al., 2013; Pereira et al., 2007; David et al., 2004), since annual precipitation patterns show that periodical summer droughts and evapotranspiration losses are high (Krishnan et al., 2012; Huxman et al., 2005).

In the recent past, precipitation shows a significant decrease in rain amount in February and March as well as a decrease in total annual rainfall on the Iberian Peninsula (Guerreiro et al., 2013; García-Barrón et al., 2013; Mourato et al., 2010; Paredes et al., 2006). A trend towards extreme events in the form of droughts is observed due to a more heterogeneous distribution of precipitation throughout the year (Zeppel et al., 2014; García-Barrón et al., 2013). These types of changes in precipitation regime have been reported as strongly affecting the local water balance (Rodrigues et al., 2011; Vaz et al., 2010; Grant et al., 2010) and carbon sink strength (Pérez-Ramos et al., 2013; Pereira et al., 2007; Granier et al., 2007; Ciais et al., 2005) of ecosystems in semi-arid regions, and are expected to increase with proceeding climate change (Bussotti et al., 2013; Guerreiro et al., 2013).

Species in semi-arid environments have developed vast structural and functional adaptations to regulate carbon assimilation and respiratory water loss (e.g. Tenhunen et al., 1987; Werner et al., 1999). Considerable knowledge has been acquired on leaf-level physiological processes in the last three decades (e.g. Beyschlag et al., 1986; Sala and Ten- hunen, 1996; Tenhunen et al., 1985, 1990; Werner et al., 2001), emphasising the role of ecophysiological adaptations to seasonality and summer drought under Mediterranean climate conditions. In these environments, lack of precipitation often interacts with excessive irradiance and high temperature, further constraining leaf carbon fixation through photoinhibition during drought (Werner et al., 2001, 2002). Cork oaks strongly reduce transpirational water loss by stomatal closure in response to drought to avoid a critical level of dehydration and hydraulic failure (Oliveira et al., 1992; Tenhunen et al., 1984, 1987; Werner and Correia, 1996; KurzBesson et al., 2006).

To investigate the influence of drought on carbon sink strength at ecosystem level, combined stomatal conductance-photosynthesis models can be used in order to disentangle regulatory processes from effects of microclimatic variations. Different descriptions of the underlying processes exist in the literature, though. For example, stomatal conductance can be modelled either as reacting to relative humidity (Ball et al., 1987) or to vapour pressure deficit (Leuning, 1995). Also, the determination of parameters in individual descriptions is different among different authors. The sensitivity of stomatal conductance to vapour pressure, for example, is often taken as a fixed value while determining only the other parameters in the coupled stomatal conductance-photosynthesis model time-variantly, although the sensitivities of stomatal conductance to photosynthesis and to vapour pressure are highly correlated. Recent studies could consequently demonstrate that changes of one single parameter, e.g. maximum carboxylation rate only or stomatal conductance sensitivity only, do not explain droughtinduced reductions in both GPP and $T$ simultaneously (Egea et al., 2011; Reichstein et al., 2003; Zhou et al., 2013). Furthermore, different temperature dependencies of e.g. maximum carboxylation or the electron transport rate have been proposed (Medlyn et al., 2002; von Caemmerer, 2000; June et al., 2004).

In the present study, we report on drought effects on a Portuguese montado ecosystem using the unique opportunity of two consecutive years of very contrasting hydrological conditions, 2011 being a wet year with a regular drought pattern occurring in summer, and 2012 being an extremely dry year with a strongly reduced precipitation amount. Particularly, 2012 showed a severe additional winter/spring drought characteristic for precipitation pattern changes in the recent past on the Iberian Peninsula (second driest year since 1950, Costa et al., 2012; Santos et al., 2013; Trigo et al., 2013). This study focuses on (1) quantifying the effects of drought on the local ecosystem water balance, overstorey and understorey GPP, as well as differences in net ecosystem carbon exchange NEE between both years, and (2) identifying physiological responses in the drought year 2012 of the $Q$. suber trees using a combined photosynthesis-stomatal conductance model and testing the model performance with different process descriptions. 


\section{Material and methods}

\subsection{Site description}

The study was conducted at the PT-Cor savannah-type flux observation site (Fig. 1) of the European Integrated Carbon Observation System (ICOS) ca. $100 \mathrm{~km}$ north-east of Lisbon, Portugal (latitude $39^{\circ} 8^{\prime} 20.7^{\prime \prime} \mathrm{N}$, longitude $8^{\circ} 20^{\prime} 3.0^{\prime \prime} \mathrm{W}$, altitude 162 ma.s.l.). The site is planted with evergreen Quercus suber (L.) trees of 209 individuals $\mathrm{ha}^{-1}$ in a Luvisol soil (Jongen et al., 2011). The tree canopy has a leaf area index LAI of $1.05 \pm 0.07 \mathrm{~m}_{\text {leaf }}^{2} \mathrm{~m}_{\text {ground }}^{-2}$, a midday gap probability $P_{\text {gap }}(0)$ of $0.76 \pm 0.03$ and an average tree canopy height of $9.7 \mathrm{~m}$ (Piayda et al., 2014). The $Q$. suber trees likely have deep soil water and groundwater access. Native annual grasses and herbs form the understorey vegetation (Jongen et al., 2013b; Dubbert et al., 2014a), which emerges after the first rains in autumn, has a peak stand height in spring (March-April), and becomes senescent at the beginning of the summer period (late May), with a maximum LAI of $0.70 \pm 0.05 \mathrm{~m}_{\text {leaf }}^{2} \mathrm{~m}_{\text {ground }}^{-2}$. The understorey vegetation density and LAI are spatially highly variable due to the heterogeneous topography and, hence, differences in soil moisture regime. The whole region is under forest management.

\subsection{Climate conditions}

The site is characterised by a Mediterranean climate with moist and mild winters and dry and hot summers. The longterm mean annual temperature is about $15.9^{\circ} \mathrm{C}$, and the annual sum of precipitation is about $680 \mathrm{~mm}$ (Jongen et al., $2013 b$ ), with a characteristic annual pattern of high winter precipitation (November to January) and summer drought from June to September (Paredes et al., 2006). The relevance of the winter precipitation for the Portuguese hydrological cycle can be easily explained by the prevailing Mediterranean-type climate that concentrates most of the precipitation during the winter half of the year, with little to no precipitation in summer. Hence, the following data treatment is based on the hydrological year beginning with the first autumn precipitation (October to September).

\subsection{Overstorey eddy covariance measurements}

The overstorey tower (Fig. 1, point 1) is set up with a Gill R3A-50 ultrasonic anemometer (Gill Instruments Ltd., Lymington, UK) in combination with a LI-7000 closed path $\mathrm{CO}_{2} / \mathrm{H}_{2} \mathrm{O}$ analyser (LI-COR, Lincoln, USA). The inlet tube has a length of $8.5 \mathrm{~m}$, is attached to one of the anemometer arms, and is operated with an average flow rate of ca. $8 \mathrm{~L} \mathrm{~min}^{-1}$. The reference cell is flushed with $\mathrm{N}_{2}$. The measurement height is about $23.5 \mathrm{~m}$ above the ground. Data are continuously acquired and processed live on a field laptop with the eddy covariance data acquisition and the EddyMeas processing software package (meteotools, Jena, Germany; Kolle and Rebmann, 2007).

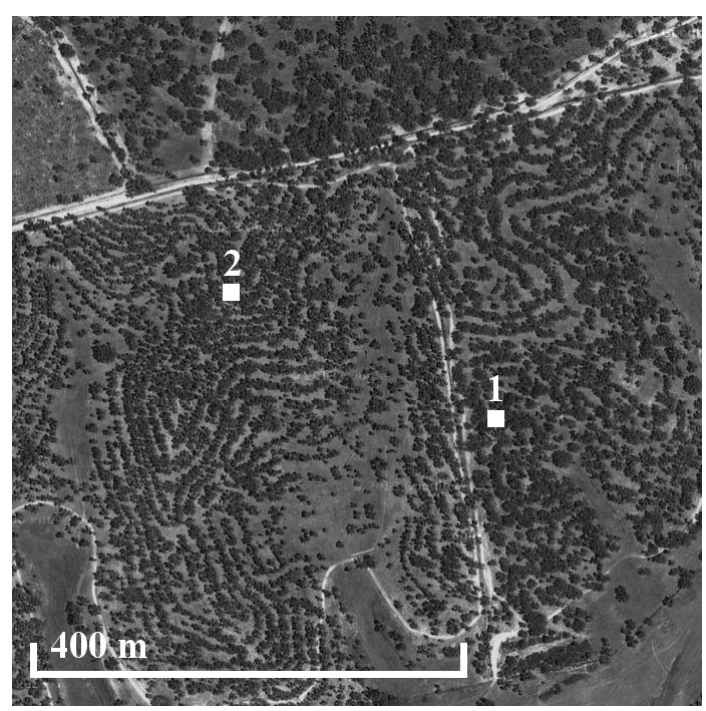

Figure 1. Satellite image of the study site $\left({ }^{\circledR}\right.$ Google Maps, 2013). (1) Position of the overstorey tower. (2) Position of the understorey tower.

At a height of $20 \mathrm{~m}$ above the ground, two upwardand downward-facing LI-190 quantum sensors (LI-COR, Lincoln, USA) and an NR-LITE net radiometer (Kipp and Zonen, Delft, the Netherlands) are attached. A radiationshielded HMP 155 probe measures air temperature $T_{\mathrm{a}}$ and relative humidity $\mathrm{rH}$ (Vaisala, Helsinki, Finland). Precipitation $P$ is measured with an ARG100 aerodynamic rain gauge (Environmental Measurements Ltd., North Shields, UK) at the tower top. The meteorological parameters are logged on a CR10X data logger (Campbell Scientific, Logan, USA).

\subsection{Understorey eddy covariance measurements}

The understorey tower was located about $286 \mathrm{~m}$ north-west of the overstorey tower (Fig. 1, point 2). It was equipped with a Gill R3-50 ultrasonic anemometer (Gill Instruments Ltd., Lymington, UK) in combination with a LI-7500A open path $\mathrm{CO}_{2} / \mathrm{H}_{2} \mathrm{O}$ analyser (LI-COR, Lincoln, USA). The gas analyser was tilted $45^{\circ}$ from the vertical, and the sensor separation was about $30 \mathrm{~cm}$. The measurement height of both sensors was $3.15 \mathrm{~m}$ above the ground. EddyMeas was used for data acquisition here as well.

At $2 \mathrm{~m}$ height above the ground, two PAR LITE quantum sensors facing upward and downward were attached to a CNR1 net radiometer (Kipp and Zonen, Delft, the Netherlands). Air temperature $T_{\mathrm{a}}$ and relative humidity $\mathrm{rH}$ were measured with an HMP 155 probe covered by a radiation shield, and atmospheric pressure $p$ was measured with a PTB 110 barometer at $1.5 \mathrm{~m}$ above the ground (Vaisala, Helsinki, Finland). The meteorological parameters were logged on a CR1000 data logger (Campbell Scientific, Logan, USA). 
A third eddy covariance system consisting of a Gill R3-50 ultrasonic anemometer in combination with a LI-7500A open path $\mathrm{CO}_{2} / \mathrm{H}_{2} \mathrm{O}$ analyser was used to test the comparability of overstorey and understorey tower systems. For a period of 1 week each, it was mounted on the overstorey and understorey towers and measured in parallel. Both systems showed high Bravais-Pearson correlation coefficients of 0.78 to 0.91 as well as small normalised root mean squared errors of 0.01 to 0.06 for water and carbon fluxes in comparison with the portable eddy system.

\subsection{Soil temperature and moisture}

Soil temperature $T_{\mathrm{s}}$ and soil moisture $\theta$ were measured at open and tree-shaded locations between the two towers. $T_{\mathrm{s}}$ was measured with PT100 PRT temperature probes (Campbell Scientific, Logan, USA) at 2, 4, 8, 16, 30, and $60 \mathrm{~cm}$ depths, with two replicates at the open location and two replicates at the shaded location. $\theta$ was measured with $10 \mathrm{hs}$ sensors (Decagon Devices, Inc., Washington, USA) at 5, 15, 30 and $60 \mathrm{~cm}$ depths, with four replicates at the open location and four replicates at the shaded location. The meteorological parameters were logged on CR1000 data loggers (Campbell Scientific, Logan, USA).

\subsection{Data treatment}

Eddy flux data were post-processed using EddySoft and Python 2.7. Half-hourly means were calculated by blockaveraging the $20 \mathrm{~Hz}$ data; time lags between $\mathrm{CO}_{2} / \mathrm{H}_{2} \mathrm{O}$ signals and vertical wind velocity were determined via crosscorrelation analysis following Aubinet et al. (1999). Whenever the cross-correlation failed for the closed path analyser signals of the overstorey tower, the dependency on $\mathrm{rH}$ was used to determine the lag for the $\mathrm{H}_{2} \mathrm{O}$ signal according to Ibrom et al. (2007). High-frequency losses were compensated for with the use of inductances derived from co-spectral analysis (Eugster and Senn, 1995). The sectorial planar fit method was used for the coordinate rotation of wind vectors (Rebmann et al., 2012; Wilczak et al., 2001). For both towers, the moisture and cross-wind correction according to Schotanus et al. (1983) was applied, and the WPL correction for flux density fluctuations was used for the $\mathrm{CO}_{2} / \mathrm{H}_{2} \mathrm{O}$ signals of the open path understorey sensor only (Leuning, 2007; Webb et al., 1980). The storage term of $\mathrm{CO}_{2}$ was calculated after Hollinger et al. (1994) and added to the turbulent $\mathrm{CO}_{2}$ flux.

For the purposes of quality control, flags were determined for every half-hourly flux value, including the following tests: the $20 \mathrm{~Hz}$ data were scanned for exceeded physical limits, change rates and variances. The stationary test of Foken and Wichura (1996) was applied to the high-frequency data based upon a $50 \%$ deviation criterion. On a half-hourly basis, the integral turbulence characteristics (ITC) were calculated following Thomas and Foken (2002) with a $30 \%$ devia- tion criterion. For the understorey tower, the parametrisation of the ITC was recalculated according to the observations. A spike detection routine was used on the half-hourly data based on the absolute median deviation (Papale et al., 2006). All quality control tests were summed up in a simplified flag system referring to Mauder and Foken (2011).

The partitioning of the net $\mathrm{CO}_{2}$ flux NEE into gross primary productivity GPP and ecosystem respiration $R_{\text {eco }}$ followed Lasslop et al. (2010), and the flux-gap filling was made according to Reichstein et al. (2005). Gaps were only filled up to a maximum gap length of 6 days.

The measured wind speed was used to calculate aerodynamic conductance $g_{\mathrm{a}}=u_{*}^{2} / u$ with the measured friction velocity $u_{*}^{2}$ and horizontal wind speed $u$. Leaf temperature is estimated using measured air temperature $T_{\mathrm{a}}$ and measured sensible heat flux $H$ via $T_{1}=T_{\mathrm{a}}+H /\left(g_{\mathrm{a}} \rho_{\mathrm{a}} c_{\mathrm{p}}\right)$, with $\rho_{\mathrm{a}}$ being the density and $c_{\mathrm{p}}$ the heat capacity of the air.

$T_{\mathrm{S}}$ and $\theta$ were integrated over the respective depths and the replicates of each site (open and shaded) are averaged. To calculate ecosystem representative $T_{\mathrm{s}}$ and $\theta$, the open and shaded sites were weighted using time-dependent $P_{\text {gap }}$, modelled from the daily course of the Sun inclination angle and the view zenith angle distribution of $P_{\text {gap }}$ (Piayda et al., 2014).

The soil heat flux $G$ was calculated from the averaged $T_{\mathrm{s}}$ profiles. To estimate the energy balance closure of the towers, the storage terms due to changes in $T_{\mathrm{a}}$ and $\mathrm{rH}$ were added to the energy balance equation and plotted against the turbulent energy fluxes for daytime values with global radiation $R_{\mathrm{g}}>20 \mathrm{~W} \mathrm{~m}^{-2}$ (Mauder et al., 2013; Foken, 2008; Twine et al., 2000). The ratio was used to correct sensible heat $H$, latent heat $\lambda E$ and evapotranspiration ET flux, with the Bowen ratio being preserved.

\subsection{Photosynthesis and stomatal conductance modelling}

The Farquhar model for photosynthesis (Farquhar et al., 1980) combined with the Leuning model for stomatal conductance (Leuning, 1995) was used in a two-leaf scheme to model gross primary productivity and evapotranspiration $\left(\mathrm{GPP}_{\mathrm{o}}\right.$ and $\left.\mathrm{ET}_{\mathrm{o}}\right)$ measured at the overstorey tower for the summer months May to September of 2011 and 2012. The separation into sunlit and shaded leaves follows De Pury and Farquhar (1997), and could be directly derived by the measured leaf projection function and LAI from (Piayda et al., 2014). For model comparison, stomatal conductance was modelled as well with the approach of Ball et al. (1987). The model was fitted to a 31 day long moving window of $\mathrm{GPP}_{\mathrm{o}}$ and $\mathrm{ET}_{\mathrm{o}}$ to gain stable median daily cycles. These were cropped to the time from sunrise to 15:00. Model fitting was done using a Nelder-Mead simplex algorithm (Nelder and Mead, 1965) with a higher-order multi-objective cost function for $\mathrm{GPP}_{\mathrm{o}}$ and $\mathrm{ET}_{\mathrm{o}}$ according to Duckstein (1981) under varying apparent maximum carboxylation rates $V_{\mathrm{c}, \max }$ 
(no separate modelling of mesophyll conductance), assimilation sensitivities $m$, vapour pressure deficit sensitivities $D_{0}$ of stomatal conductances $g_{\mathrm{s}}$ and optimum temperatures $T_{\mathrm{opt}}$ of the maximum electron transport rates $J_{\max }$. Three different $T_{\text {opt }}$ descriptions were used for model comparison. The uncertainty of inferred parameters was estimated using bootstrap. See Appendix A for detailed model equations.

\section{Results and discussion}

Ecosystem fluxes for the hydrological years 2011 and 2012 (October 2010 to September 2012) are discussed in the following. Flux time series are only compared when data availability is given for both hydrological years, but not on an annual sum basis.

The dominant wind direction changes during the season. Absolute values of flux measurements of the overstorey tower are thus not directly comparable to the absolute values of the understorey tower, due to changing footprint area and the heterogeneity of the ecosystem. However, comparisons of the intra-annual pattern of ecosystem fluxes between both towers and inter-annual changes between both the years 2011 and 2012 are possible, and are conducted in the following.

\subsection{Meteorological and environmental conditions}

Water scarcity is the most important factor for ecosystem productivity in savannah-type ecosystems (Pereira et al., 2007). Drought severity and impact on vegetation depends on the timing and amount of precipitation $P$ (Peñuelas et al., 2004). The hydrological years 2011 and 2012 mark, therefore, exceptional years on the Iberian Peninsula. Precipitation $P$ was $34 \%$ higher in 2011 and 39\% lower in 2012 compared to the long-term average precipitation of about $680 \mathrm{~mm}$ (Jongen et al., 2013a) (Fig. 2a and b). In particular, the winter of 2011/2012 was very dry over south-western Iberia, with only about $20 \%$ of the long-term precipitation (Santos et al., 2013; Trigo et al., 2013). 2012 was the second driest year since 1950 . The last negative $P$ anomaly of comparable severity occurred in the drought year 2004/2005 (Paredes et al., 2006; Santos et al., 2007).

The intra-annual pattern of precipitation has especially changed in 2012. Total annual reduction to the previous year (2011) was $495 \mathrm{~mm}$, of which $68 \%$ occurred during a long drought event in winter and early spring (December-March). The beginning of autumn precipitation was also delayed by almost a month in 2012. Winter precipitation is the most important for replenishing the soil and groundwater reservoirs after the summer drought, but the winter precipitation period was shortened and interrupted for about 4 months in the 2012 hydrological year. These phenomena, i.e. reduced annual $P$, additional winter/spring drought, and prolonged summer drought, are characteristic of observed $P$ extremes

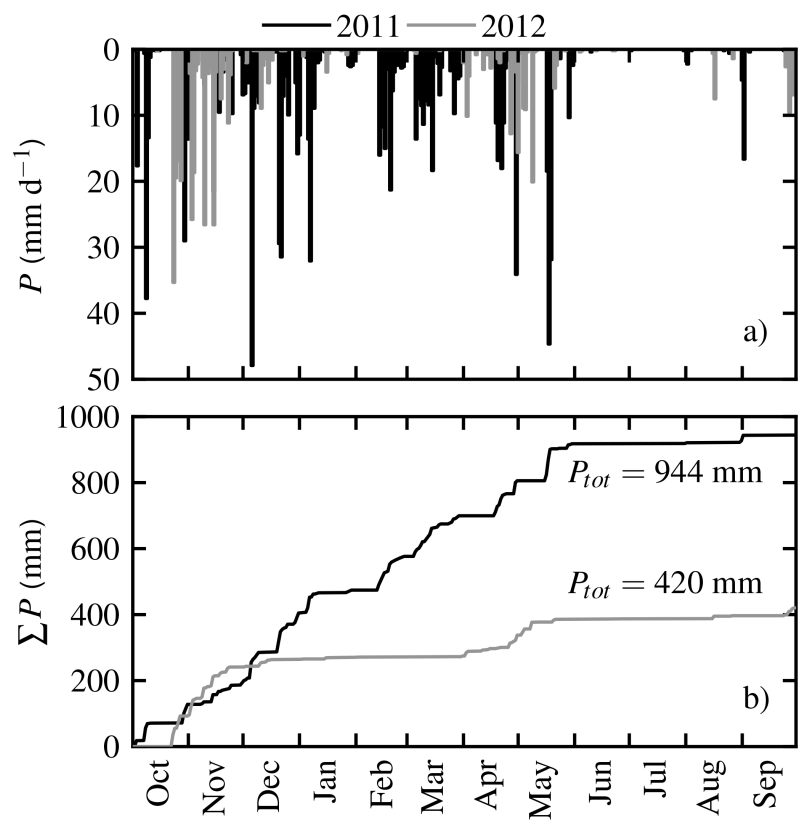

Figure 2. (a) Daily sum of precipitation $P$ for 2011 (black) and 2012 (grey). (b) Cumulative precipitation $P$ for 2011 (black) and 2012 (grey) based on half-hourly data.

in the last decades (e.g. Guerreiro et al., 2013; Paredes et al., 2006).

We first address the question of changes in environmental and climatic components between both years, which may have caused significant changes in ecosystem functioning. The distributions of the most relevant climatic and environmental variables for plant functioning are therefore analysed in quantile-quantile $(Q-Q)$ plots in Fig. 3. Air temperature $T_{\mathrm{a}}$ (Fig. 3a) and incoming photosynthetically active radiation PAR (data not shown) showed only minor changes between the 2 years, so that plant available energy in both years was comparably high. In contrast, moisture-related variables showed large deviations from the one-to-one line in the $Q-Q$ plots (Fig. 3b-d). All precipitation $P$ intensities of 2012 stayed well below the ones in 2011 (Fig. 3b). Air vapour pressure deficit vpd was considerably increased at high deficits in 2012 compared to 2011 (Fig. 3c). This comes from lower absolute humidity because air temperature $T_{\mathrm{a}}$ did not change substantially. Possible reasons are either diminished local ecosystem evapotranspiration ET due to diminished soil moisture (Fig. 3d) and plant transpiration or less air moisture input by incoming air masses from the ocean. Soil moisture was significantly decreased in 2012 compared to 2011 (Fig. 3d), which is exhibited especially in the missing medium soil moisture amounts. The contribution of local ET to the observed reduction in vpd was estimated by approximating the average contribution of local ET to the absolute humidity of the atmospheric boundary layer. $50 \%$ of absolute humidity reduction in 2012 compared to 2011 could be 

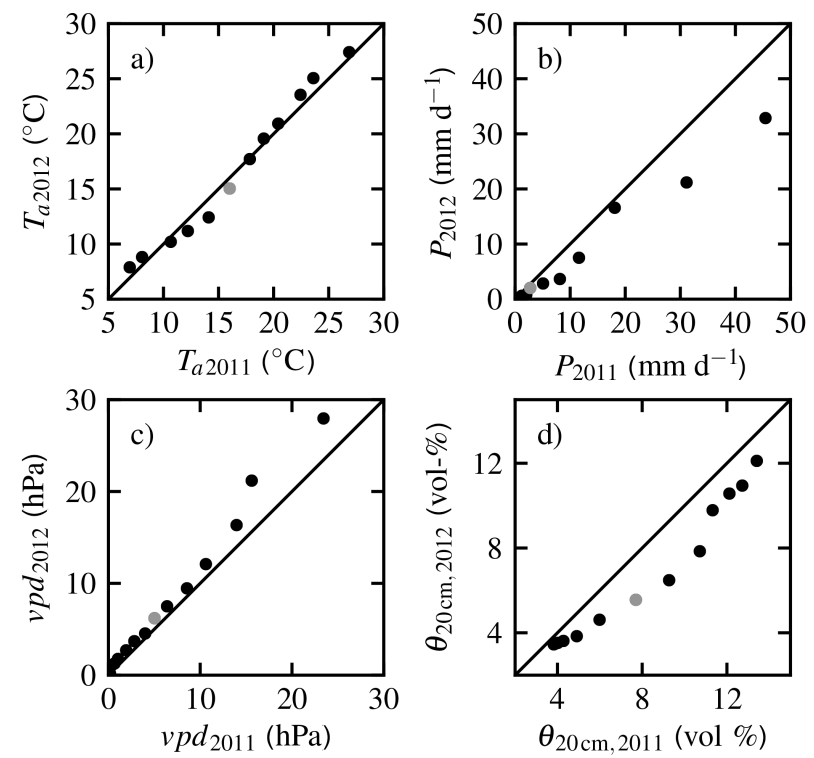

Figure 3. Quantile-quantile plot of important climate and environmental parameters for the years 2011 and 2012 based on daily averages. Black dots represent the 0.01, 0.05, 0.1, 0.2, 0.3, 0.4, 0.6, 0.7, $0.8,0.9,0.95$, and 0.99 quantiles of the respective distribution. Grey dots represent the 0.5 quantile. (a) Air temperature $T_{\mathrm{a}}$, (b) precipitation $P$, and (c) vapour pressure deficit of the air vpd, each measured at $20 \mathrm{~m}$ height above the ground. (d) Soil moisture in the first $20 \mathrm{~cm}$ $\theta_{20 \mathrm{~cm}}$ (root zone of understorey vegetation).

explained by a reduced contribution of local ET. This illustrates the strong influence of ET on local hydrological conditions and the reinforcement of plant drought stress due to increased vpd.

The ecosystem, therefore, faced increased transpirational demand from higher atmospheric vpd combined with strongly decreased soil water availability, which resulted in high water stress for the trees but also for understorey vegetation in 2012 compared to 2011. In the following, the effect of decreased water availability on the ecosystem water budget is discussed.

\subsection{Drought influence on ecosystem water balance}

Evapotranspiration ET is the major component of total water efflux in Mediterranean ecosystems on an annual basis (Huxman et al., 2005). A comparably small amount of precipitation is left for groundwater recharge and runoff. ET usually peaks in May before the onset of drought in the beginning of June in Mediterranean ecosystems (Vargas et al., 2013), but ecosystem evapotranspiration measured here at the overstorey tower $\mathrm{ET}_{\mathrm{o}}$ (Fig. 4b) peaked within the summer drought period in June to July in 2011. This behaviour is typical of montado ecosystems with groundwater access of the trees (Paco et al., 2009; Pereira et al., 2007; David et al., 2007, 2004). $\mathrm{ET}_{\mathrm{o}}$ showed a slight peak shift towards spring in 2012 , and was diminished by $26 \%$ compared to 2011 . The
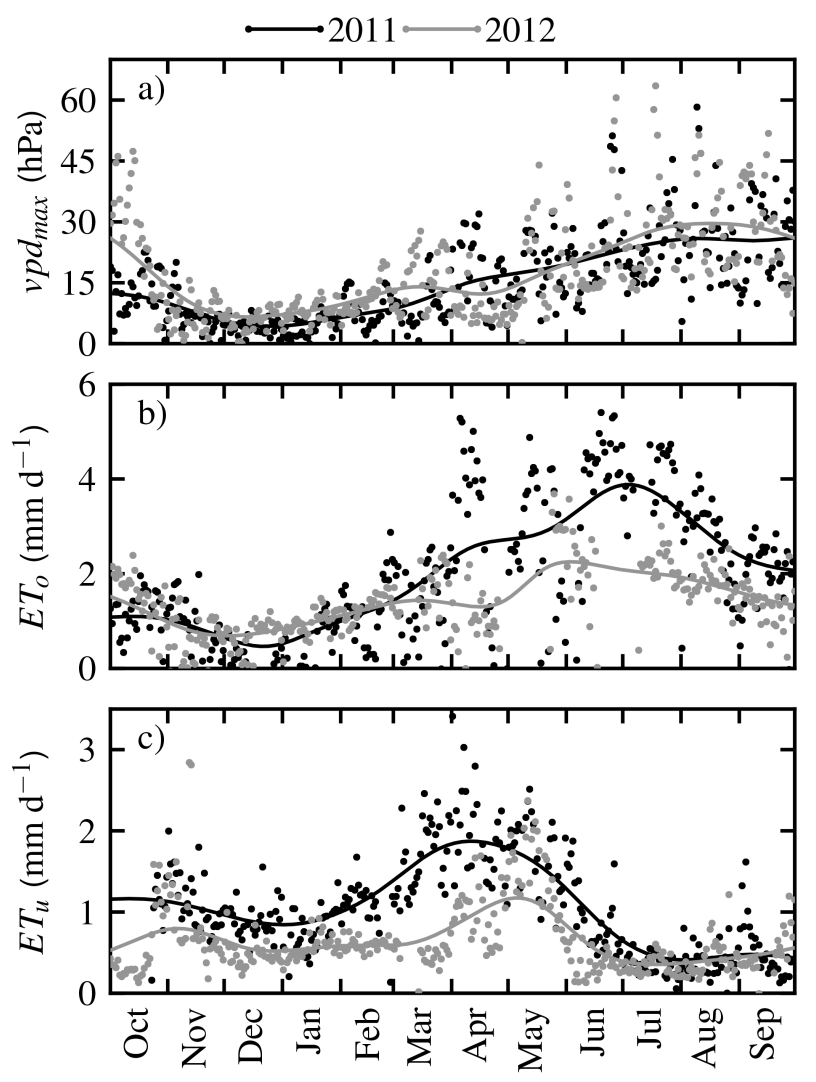

Figure 4. (a) Maximum daily vapour pressure deficit $\operatorname{vpd}_{\max }$, (b) daily sum of ecosystem evapotranspiration $\mathrm{ET}_{\mathrm{O}}$ and (c) daily sum of understorey transpiration and soil evaporation $\mathrm{ET}_{\mathrm{u}}$ for 2011 (black) and 2012 (grey). Lines mark kernel regressions.

major decrease occurred in late spring and summer (March to September), although the major reduction in precipitation $P$ occurred in winter and early spring (December to March) (Fig. 2b). When atmospheric demand (Fig. 4a) and energy input into the system increased in the spring of 2012, the Q. suber trees were not able to maintain transpiration $T$ as high as in 2011. This indicates that, most likely, the deep soil and/or groundwater reservoirs were not refilled after the summer of 2011 due to the dry winter as displayed by soil moisture observations at $60 \mathrm{~cm}$ in depth (Fig. 5b). However, the strongly diminished transpiration $T$ led to a non-significant increase in maximum daily leaf temperature $T_{1, \max }$ of only $1.7^{\circ} \mathrm{C}$ during the summer period of 2012 . The small influence of the reduced transpirational cooling on leaf temperature could be attributed to the high aerodynamic conductance $g_{\mathrm{a}}$ in this open canopy, enabling comparably high energy transport by sensible heat.

Evapotranspiration measured at the understorey tower $\mathrm{ET}_{\mathrm{u}}$ peaked from March to April 2011 before the beginning of the summer die back of the understorey vegetation, which is rather typical in savannah-type ecosystems (e.g. Paco et al., 2009). $\mathrm{ET}_{\mathrm{o}}$ was reduced, though, by $38 \%$ in 2012 compared to 2011. The peak was slightly delayed under drought con- 

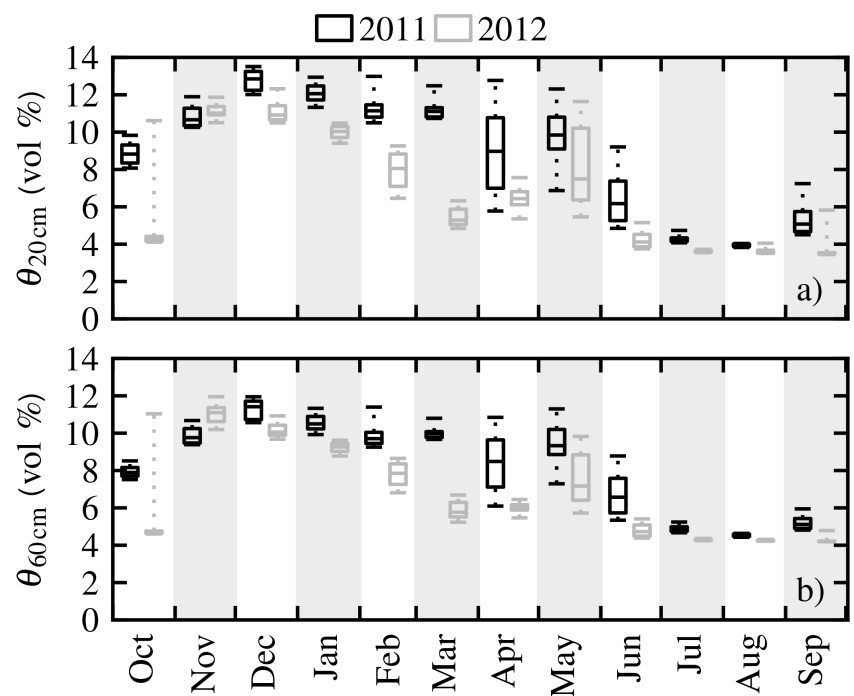

Figure 5. Box plot of monthly volumetric soil moisture (a) down to $20 \mathrm{~cm}$ depth $\theta_{20 \mathrm{~cm}}$ (root zone of understorey vegetation) and (b) down to $60 \mathrm{~cm}$ depth $\theta_{60 \mathrm{~cm}}$ for the years 2011 (black) and 2012 (grey). The central line marks the median, and the box marks the 0.25 and 0.75 quantiles. Dashed lines mark the 0.05 and 0.95 quantiles. Data within a 2 day interval after a rain event were excluded.

ditions in 2012, in contrast to ecosystem $\mathrm{ET}_{\mathrm{o}}$. The late onset of autumn precipitation $P$ in October and, additionally, the missing recharge of upper soil moisture in winter (Fig. 5a) had an immediate impact on $\mathrm{ET}_{\mathrm{u}}$, inhibiting plant growth and herbaceous transpiration (see Sect. 3.3). $\mathrm{ET}_{\mathrm{o}}$, on the other hand, was influenced from March onwards only. The precipitation events occurring in April and March 2012 (Fig. 2a) were not able to increase $\mathrm{ET}_{\mathrm{u}}$ up to the level of 2011, even though the atmospheric demand was slightly higher in 2012 (Fig. 3c). This can be explained on the one hand by very low soil moisture up to $20 \mathrm{~cm}$ in depth in October and from March onwards (Fig. 5a), which prevented soil evaporation, and, on the other hand, by the strong reduction in plant cover leading to a reduced contribution of herbaceous plant transpiration to $\mathrm{ET}_{\mathrm{u}}$ (see Sect. 3.3).

Precipitation effectiveness $\mathrm{ET}_{\mathrm{o}} / P$ indicates the amount of total precipitation $P$ used for actual ecosystem evapotranspiration $\mathrm{ET}_{\mathrm{o}} . \mathrm{ET}_{\mathrm{o}} / P=86 \%$ in 2011 , which is high but comparable to other studies (Sala and Tenhunen, 1996; Piñol et al., 1991). However, the strong reduction in ecosystem evapotranspiration $\mathrm{ET}_{\mathrm{o}}$ of $26 \%$ in 2012 was vastly exceeded by the reduction in precipitation $P$ of $54 \%$. This confirms recent results from Besson et al. (2014) showing a certain resilience of $Q$. suber tree transpiration to annual water shortages. This led to $\mathrm{ET}_{\mathrm{o}} / P$ of $122 \%$ in 2012 , which is, to our knowledge, the highest value reported for montado ecosystems so far. Hence, more water evaporated from the soil and was transpired by the trees than was brought into the ecosystem by precipitation. This was possible due to the deep soil or groundwater access of the trees maintaining a relatively high transpiration rate throughout the summer, but it also left no water for groundwater replenishment or runoff generation (cf. Sala and Tenhunen, 1996).

Ecosytem productivity was markedly changed in 2012 due to the strong alterations in the water balance, which will be discussed in the following.

\subsection{Understorey growth inhibition}

The local understorey vegetation consists of native annual grasses and herbs (Jongen et al., 2013b; Dubbert et al., 2014a). The species are adapted to regular summer droughts by seed formation in spring before the onset of the summer droughts. They survive the dry periods as seeds and germinate again at the onset of autumn precipitation. Species abundance during spring thus depends on the amount of previous winter precipitation (Figueroa and Davy, 1991). The timing of the first autumn rains and rewetting of the soils is therefore of great importance for germination success, the number of individuals and plant productivity (Jongen et al., 2013c; de Dios Miranda et al., 2009).

The understorey showed a typical annual cycle of gross primary productivity $\mathrm{GPP}_{\mathrm{u}}$ in 2011 (Fig. 6c) for savannahtype understorey vegetation, with the growth onset at the end of October (Ma et al., 2007). Carbon uptake peaked in February to March and ended with the complete die back at the end of May. GPP $\mathrm{G}_{\mathrm{u}}$ was strongly reduced, by 53\%, in 2012 compared to 2011. A small $\mathrm{GPP}_{\mathrm{u}}$ peak occurred along with precipitation $P$ in April and May (Fig. 2). The reduction in $\mathrm{GPP}_{\mathrm{u}}$ can be explained by the very low soil moisture $\theta_{20 \mathrm{~cm}}$ during October 2011 (Fig. 5a) due to the late onset of autumn precipitation $P$ inhibiting seed germination. $\theta_{20} \mathrm{~cm}$ was lower during the entire year of 2012 in comparison to 2011, particularly over the main growth period of the understorey vegetation from January to April. It was up to $52 \%$ lower in March 2012, inhibiting further growth during winter/spring, and probably caused higher seedling mortality. Dubbert et al. (2014a) reported a maximum understorey vegetation cover in this ecosystem of about $80 \%$ for 2011 that was reduced to about $25 \%$ during the same period in 2012 (data for 2012 not shown). Similar effects on seedling germination and mortality were shown by others (Peco and Espigares, 1994; Espigares and Peco, 1995, 1993) under artificial rainfall treatments, and could be shown here under natural conditions.

\subsection{Ecosystem productivity reduction}

Most European Mediterranean savannah-like ecosystems show a severe drop in gross primary productivity during summer (June to August) framed by a major peak in early spring (April to May) and a minor peak at the onset of autumn rain (Baldocchi et al., 2009).

In our ecosystem, gross primary productivity measured at the overstorey tower $\mathrm{GPP}_{\mathrm{o}}$ showed, in this respect, atypical annual behaviour, with a very late peak from June to July 
(Fig. 6b). The amount of carbon gained was also higher compared to other Mediterranean evergreen woodlands, in particular during the drought period in summer (Baldocchi et al., 2009; Ma et al., 2007). This annual pattern is rather more characteristic of temperate than semi-arid ecosystems. The $Q$. suber trees must have deep soil water or groundwater access in "regular" hydrological years, as shown in Sect. 3.2. This enabled them to maintain high productivity during the summer period despite high atmospheric water demand and low topsoil soil moisture.

Gross primary productivity $\mathrm{GPP}_{\mathrm{o}}$ showed almost the same seasonal timing in 2012 compared to 2011, but was strongly reduced by $28 \%$ (Fig. 6b). The major reduction took place in spring and summer (April to September) together with the reduction in evapotranspiration $\mathrm{ET}_{\mathrm{o}}$ (Fig. 4b) when atmospheric demand was high and the emptied deep soil and groundwater reservoirs were unable to supply sufficient water (see Sect. 3.2) in 2012 compared to a regular year. This confirms the results of Pereira et al. (2007), who showed that drought effects on sclerophyllous trees became apparent only after the depletion of the deep soil and groundwater reserves. Despite a delayed bud burst in spring, a significant difference in leaf area index LAI could not be observed during the summer period by the long-term leaf area index observations of Costa e Silva et al. (2014). Reductions in $\mathrm{GPP}_{\mathrm{o}}$ and $\mathrm{ET}_{\mathrm{o}}$ can hence be attributed solely to the leaf physiological responses discussed in Sect. 3.6.

\subsection{Net ecosystem carbon exchange reduction}

The net ecosystem carbon flux $\mathrm{NEE}_{\mathrm{o}}$ was strongly reduced by $38 \%$ in the drought year of 2012 compared to the wet year of 2011 (Fig. 6a). The ecosystem was, however, a carbon sink in both years on an annual basis, even though reductions in precipitation $P$ (Fig. 2) and gross primary productivity $\mathrm{GPP}_{\mathrm{o}}$ (Fig. 6b) were severe in 2012. Pereira et al. (2007) found similar behaviour in another montado ecosystem in Portugal. It still demonstrates here once more that precipitation is the dominant environmental variable for inter-annual change of NEE in semi-arid ecosystems, even in ecosystems with groundwater access. The reduction in carbon sink strength took place mainly in summer (May to September) along with the strongest reduction in gross primary productivity $\mathrm{GPP}_{\mathrm{o}}$ (Fig. 6b) caused by the lack of water availability for the $Q$. suber trees (cf. Sect. 3.2). $\mathrm{GPP}_{\mathrm{o}}$ exhibited a reduction of $28 \%$ in 2012 compared to 2011 , while $R_{\text {eco }}$ showed a reduction of only $16 \%$. $R_{\text {eco }}$ is mainly reduced in summer (July to September, data not shown), where soil moisture in the upper soil layer $\theta_{20 \mathrm{~cm}}$ is low in both years due to the regular summer drought (Fig. 5a), and inter-annual differences are small. $\mathrm{NEE}_{\mathrm{o}}$ is therefore much more driven by $\mathrm{GPP}_{\mathrm{o}}$ than by $R_{\text {eco }}$ in the ecosystem studied here. Reichstein et al. (2002) hypothesised that gross primary productivity $\mathrm{GPP}_{\mathrm{o}}$ should be less affected by drought than ecosystem respiration $R_{\text {eco }}$ in ecosystems with large subsoil water reservoirs, because $R_{\text {eco }}$
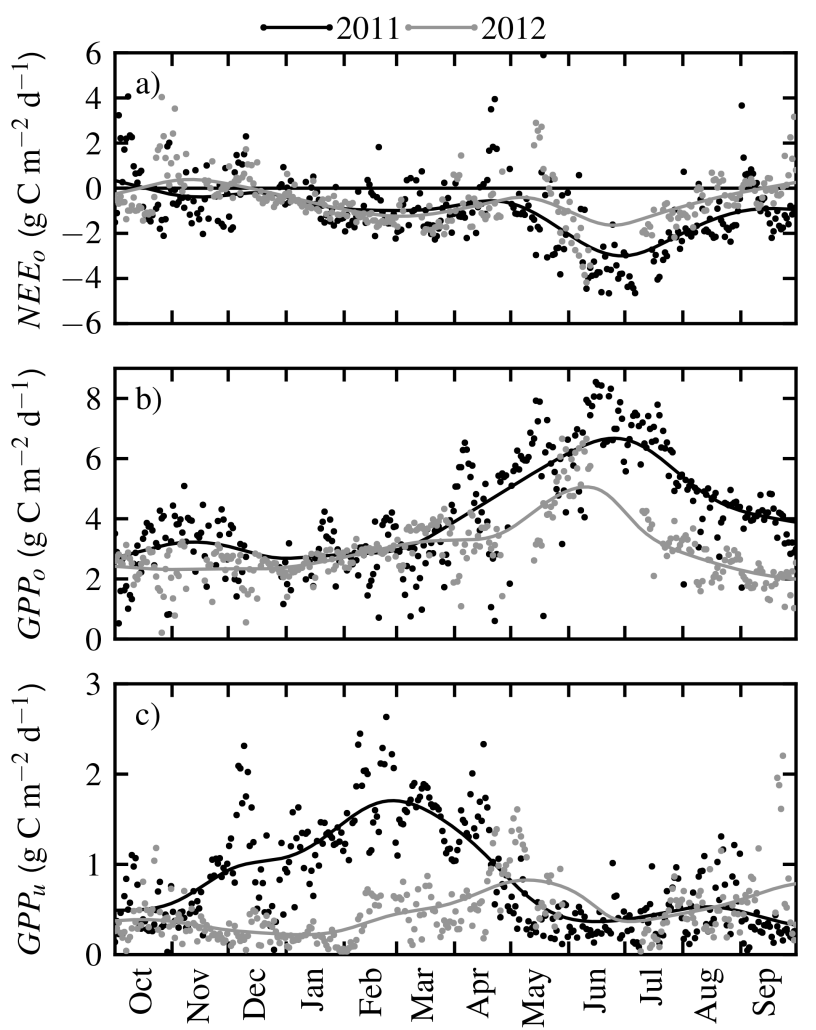

Figure 6. (a) Ecosystem net carbon exchange $\mathrm{NEE}_{\mathrm{O}}$, (b) ecosystem gross primary productivity $\mathrm{GPP}_{\mathrm{O}}$, (c) understorey gross primary productivity $\mathrm{GPP}_{\mathrm{u}}$ for 2011 (black) and 2012 (grey). Dots mark daily sums, and lines are kernel regressions.

depends on soil moisture and soil temperature, but it is hot and dry almost every summer in the Mediterranean, so that the lack of soil moisture in the upper soil inhibits soil respiration during summer and largely reduces the contribution of $R_{\text {eco }}$ to inter-annual variations (e.g. Unger et al., 2009). This could also be the reason for the controversial finding of Valentini et al. (2000) that $R_{\text {eco }}$ becomes less important for variations of NEE with decreasing latitude in the Northern Hemisphere. It is, however, clear that vastly different $\mathrm{GPP}_{\mathrm{o}}$ and $R_{\text {eco }}$ cannot be sustained over a long time; $R_{\text {eco }}$ base rates have to adapt in the long term.

\subsection{Drought impact on tree physiology}

Multiple physiological mechanisms of plant responses to drought, excessive irradiance and high temperatures have been recognised on the leaf level, such as reduction of exposed leaf area or leaf shedding (Beyschlag et al., 1986; Sala and Tenhunen, 1996; Tenhunen et al., 1985, 1990; Werner et al., 2001). To avoid hydraulic failure or photodamage, carboxylation efficiency $V_{\mathrm{c}, \max }$ and/or stomatal conductance $g_{\mathrm{s}}$ can be down-regulated, restricting water loss and carbon assimilation and hence increasing photorespiration as a protective electron sink (Farquhar and Sharkey, 1982; Cowan, 
1977; Tenhunen et al., 1987; Matthews and Boyer, 1984; Ehleringer and Cook, 1984). The photosynthesis apparatus can further adapt to altered environmental conditions by changing the rigidity of the membranes, thus altering the temperature optimum of, for example, electron transport rates (Kattge and Knorr, 2007; von Caemmerer, 2000; Berry and Björkman, 1980).

There are different levels of complexity on how to describe photosynthesis in the literature. We focus here on Farquhartype models of photosynthesis (Farquhar et al., 1980). There are three mechanisms that differ strongly between the different models of vegetation-atmosphere exchange: (1) the reactions to soil water stress, (2) the formulations used for the description of stomatal conductance, and (3) the reactions to heat stress. How plants react to water stress is probably the least well-described mechanism in photosynthesis models. The different ecosystem and land surface models differ strongly in how they react to soil water stress. The widely used community land model CLM, for example, reduces apparent carboxylation efficiency $V_{\mathrm{c}, \max }$ under drought (Oleson et al., 2010), which then indirectly reduces stomatal conductance as well, while the ORCHIDEE land surface scheme or the BEPS model down-regulate stomatal conductance directly, leaving $V_{\mathrm{c}, \max }$ unchanged (Liu et al., 2014; Krinner et al., 2005; Verbeeck et al., 2011).

There is also a great variety of descriptions of stomatal conductance (cf. Damour et al., 2010). Most large-scale models apply the formulation of Ball et al. (1987) though, the so-called Ball-Berry or, sometimes, Ball-Woodrow-Berry model (cf. Eq. A12). Leuning (1995) argued that stomata under controlled conditions react to vapour pressure deficit rather than relative humidity, and proposed an alternative form of the Ball-Berry model (cf. Eq. A11), the so-called Leuning model or, sometimes, Ball-Berry-Leuning formulation, but the photosynthesis models also differ in their reactions to heat stress. The physiological literature is still discussing whether or not heat only changes thylakoid membrane properties, limiting electron transport (von Caemmerer, 2000; June et al., 2004), or whether heat also inhibits enzyme activities, i.e. also carboxylation rates (Medlyn et al., 2002; Kattge and Knorr, 2007).

Gross primary productivity $\mathrm{GPP}_{\mathrm{o}}$ and evapotranspiration $\mathrm{ET}_{\mathrm{o}}$ were modelled here for the period May to September to investigate drought impact on $Q$. suber tree physiology on the ecosystem scale and further test the different model formulations described above. Differences between both years were most prominent from May to September, understorey vegetation had already vanished, and soil evaporation was low compared to tree transpiration (Fig. 4c).

The following discussion includes the question of (1) whether a down-regulation of carboxylation efficiency $V_{\mathrm{c} \text {,max }}$ only or stomatal sensitivity $m$ only is sufficient to describe the ecosystem behaviour in both years. (2) It evaluates the performance of the two prominent stomatal conductance formulations. (3) It compares different representations of photo- synthetic temperature dependencies. (4) It discusses possible reasons for down-regulation of stomatal conductance $g_{\mathrm{s}}$ and carboxlation $V_{\mathrm{c}, \max }$, (5) disentangling the causes of downregulation of stomatal conductance $g_{\mathrm{s}}$. (6) The unexpected change in optimal temperature $T_{\mathrm{opt}}$ between the 2 years is discussed.

First, $\mathrm{GPP}_{\mathrm{o}}$ and $\mathrm{ET}_{\mathrm{o}}$ were modelled by either allowing the model to adapt each day only $\left(V_{\mathrm{c}, \max }\right)$ or the slope $m$ of the Ball-Berry stomatal conductance formulation only (Ball et al., 1987) (Eq. A12). The model was not able to reproduce the observations with sufficient performances in both cases, especially in 2012. The goodness of fit to the observed data steadily decreased with ongoing summer drought. $\mathrm{GPP}_{\mathrm{o}}$ and $\mathrm{ET}_{\mathrm{o}}$ could be successfully modelled if both, $V_{\mathrm{c}, \max }$ and $m$, were allowed to adapt daily to changing environmental conditions, leading to constantly high Nash-Sutcliffe model efficiencies of $\overline{\varepsilon_{\mathrm{GPP}_{\mathrm{o}}}}=0.81$ and $\overline{\varepsilon_{\mathrm{ET}_{\mathrm{o}}}}=0.89$ for 2011 and $\overline{\varepsilon_{\mathrm{GPP}_{\mathrm{o}}}}=0.80$ and $\overline{\varepsilon_{\mathrm{ET}_{\mathrm{o}}}}=0.76$ for 2012 .

Second, the same model calibration experiment was performed with the Leuning model of stomatal conductance (Leuning, 1995) (Eq. A11). The Leuning model has, however, an additional model parameter $D_{0}$ which describes the sensitivity of the stomata to changes in vapour pressure deficit vpd. The Leuning model showed comparably high model performances to the Ball-Berry model in both years. When the Leuning model was used in earlier studies (e.g. Wang and Leuning, 1998), $D_{0}$ was fixed to a constant value. This implies that stomatal conductance sensitivity to vpd needs always to change similarly to the sensitivity to assimilation. Model performance decreased considerably if $D_{0}$ was fixed here. This is because $m$ and $D_{0}$ are highly correlated in the Leuning model (cf. Fig. 7b and d). This strict coupling is likely incorrect here, since daily maximum vpd during the summer drought period was not significantly different between both years (only $1.3 \mathrm{hPa}$ increase on average), but a strong decrease in $V_{\mathrm{c}, \max }$ could be observed (see below). Consequently, a decrease in model performance occurred when $D_{0}$ was set constant. Enabling the $Q$. suber trees to regulate stomatal response to vpd and assimilation $A$ separately was necessary for explaining observed $\mathrm{GPP}_{\mathrm{o}}$ and $\mathrm{ET}_{\mathrm{o}}$.

The first two points illustrate that the plants needed to regulate their potency of possible carbon assimilation, but wanted to increase how swift stomata react to changes. The reduction in the maximum carboxylation rate $V_{\mathrm{c}, \max }$, though, was about $43 \%$, while the increase in the slope $m$ was about $9 \%$ or $29 \%$, depending on whether the calculation followed Ball et al. (1987) or Leuning (1995), respectively. The increase in $m$ is not significant when the bootstrapped uncertainty is considered. Still, a significant overall decrease in stomatal conductance $g_{\mathrm{s}}$ of about $37 \%$ was observed.

Third, the temperature dependency of photosynthetic activity has generally been attributed to two different processes in previous publications. Medlyn et al. (2002) and Kattge and Knorr (2007) described the temperature dependency of both, the maximum carboxylation rate $V_{\mathrm{c}, \max }$ of the $\mathrm{Ru}-$ 

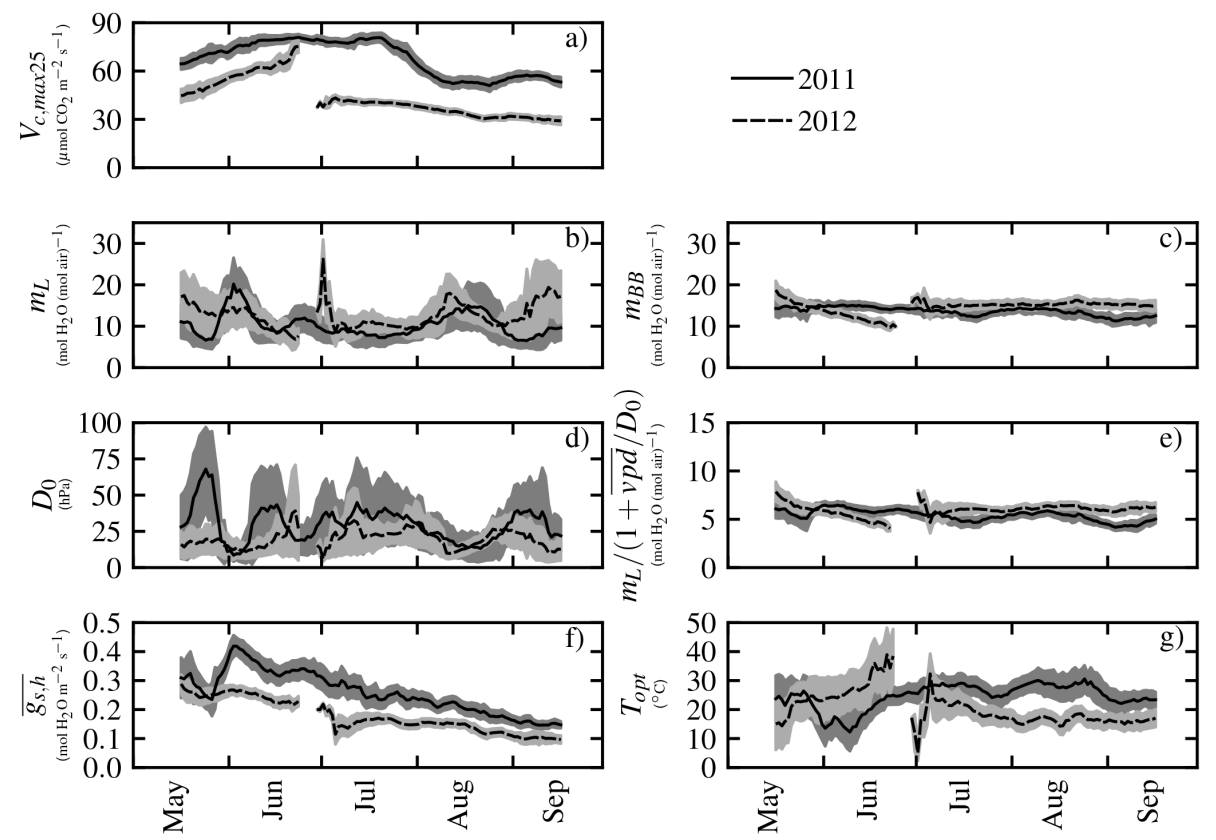

Figure 7. Daily values for (a) apparent maximum carboxylation rate at $25^{\circ} \mathrm{C} V_{\mathrm{c}, \max 25}$, (b) assimilation sensitivity parameter $m_{\mathrm{L}}$ of the Leuning model, (c) assimilation sensitivity parameter $m_{\mathrm{BB}}$ of the Ball-Berry model, (d) vapour pressure deficit sensitivity parameter $D_{0}$, (e) fraction $m_{L} /\left(1+\left(\overline{\mathrm{vpd}} / D_{0}\right)\right)$ relating assimilation $A$ and stomatal conductance $g_{\mathrm{s}}$, (f) daily median stomatal conductance for water vapour $\overline{g_{\mathrm{S}, \mathrm{h}}}$ during daytime, and (g) optimal temperature of electron transport $T_{\mathrm{opt}}$. The model is fitted to median daily cycles of gross primary productivity $\mathrm{GPP}_{\mathrm{o}}$ and evapotranspiration $\mathrm{ET}_{\mathrm{O}}$ of the $Q$. suber trees in a 31 day long moving window for the summer period of 2011 (solid line, dark uncertainty band) and 2012 (dashed, light uncertainty band).

bisco enzyme and the maximum electron transport rate $J_{\max }$ by a peaked function, according to Johnson et al. (1942) (Eq. A7). An increase in enzyme activity with temperature is followed by a decrease above an optimum temperature $T_{\text {opt }}$ due to enzyme deactivation (case 1). Von Caemmerer (2000), among others, rather attributed a possible decrease in the activity of the photosynthetic apparatus at high temperatures to thylakoid membrane properties only, limiting electron transport and thus changing with leaf temperature, so only $J_{\max }$ is down-regulated above an optimum temperature $T_{\mathrm{opt}}$ (Eq. A7), but $V_{\mathrm{c}, \max }$ increases monotonically with a typical Arrhenius-type function (Eq. A6, case 2). This was simplified by June et al. (2004) using a Gaussian temperature dependency instead of the original formulation (Eq. A9, case $3)$. Here, all cases showed comparable model performances, and no apparent differences in $\mathrm{GPP}_{\mathrm{o}}$ and $\mathrm{ET}_{\mathrm{o}}$ could be noticed. Thus, neither case 1 nor case 2 could be falsified here. Case 1 to case 3, however, show a decreasing demand for parametrisation (case 1: six, case 2: four, and case 3: three parameters). Despite the entropy factors of carboxylation $\Delta S_{V}$ and electron transport $\Delta S_{J}$ (case 1 and case 2) and optimum temperature $T_{\mathrm{opt}}$ (case 3), all parameters were fixed to literature values (Table 1). Case 3 , although containing only one parameter for optimisation like case 2 , showed a more robust computational performance, with the fastest optimisation by the Nelder-Mead algorithm (Nelder and Mead, 1965) among all cases.

Fourth, multiple reasons for down-regulation of photosynthesis under drought conditions are known, ranging from damage of involved enzymes due to high leaf temperatures, inhibition of the photosynthetic apparatus to avoid excess energy in the leaves, to insufficient availability of nitrogen inside the leaves (Tenhunen et al., 1987; Werner et al., 1999), but protection of the photosynthetic apparatus during environmental stress comes at the cost of reduced carbon sequestration (Tenhunen et al., 1990; Werner et al., 1999; Werner and Correia, 1996). Excessive radiation and high temperatures provide the risk of photoinhibition and photodamage under reduced $\mathrm{CO}_{2}$ supply due to stomatal closure and low water potentials (Werner et al., 2002). Stomatal conductance $g_{\text {s }}$ was strongly reduced by $37 \%$ in 2012 compared to 2011 (Fig. 7f), although differences in daily maximum vpd during the summer drought period were not significant (only $1.3 \mathrm{hPa}$ increase on average) between both years (Fig. 4a). It is thus very likely that the trees suffered from depleted deep soil or groundwater reservoirs due to the missing recharge by winter precipitation, since upper soil water content values were comparable during summer (Fig. 5a and b). This is evidence that the plant water status of $Q$. suber trees is strongly influenced by access to groundwater here, and a down-regulation of transpiration occurred to avoid hydraulic failure (David 
Table 1. Parameters used in the photosynthesis-stomatal conductance model. The offset parameter $b$ was estimated first with an optimisation on the entire data set and then set constant in following model runs.

\begin{tabular}{|c|c|c|c|}
\hline Parameter & Value & Unit & Source \\
\hline$\alpha$ & 0.28 & - & Beerling and Quick (1995) \\
\hline$b$ & $4300 \times 10^{-6}$ & $\operatorname{mol}\left(\mathrm{H}_{2} \mathrm{O}\right) \mathrm{m}^{-2} \mathrm{~s}^{-1}$ & Site average \\
\hline$E_{\mathrm{C}}$ & 59356 & $\mathrm{~J} \mathrm{~mol}^{-1}$ & Farquhar et al. (1980) \\
\hline$E_{J_{\max }}$ & 35870 & $\mathrm{~J} \mathrm{~mol}^{-1}$ & Medlyn et al. (2002) \\
\hline$E_{\mathrm{O}}$ & 35948 & $\mathrm{~J} \mathrm{~mol}^{-1}$ & Farquhar et al. (1980) \\
\hline$E_{\mathrm{Rd}}$ & 50967 & $\mathrm{~J} \mathrm{~mol}^{-1}$ & Collatz et al. (1992) \\
\hline$E_{V_{\mathrm{c} \text { max }}}$ & 58520 & $\mathrm{~J} \mathrm{~mol}^{-1}$ & Farquhar et al. (1980) \\
\hline $\mathrm{Hd}_{J}$ & 220000 & $\mathrm{~J} \mathrm{~mol}^{-1}$ & von Caemmerer (2000) \\
\hline $\mathrm{Hd}_{V}$ & 200000 & $\mathrm{~J} \mathrm{~mol}^{-1}$ & Medlyn et al. (2002) \\
\hline$K_{\mathrm{C}_{25}}$ & $460 \times 10^{-6}$ & $\operatorname{mol}\left(\mathrm{CO}_{2}\right) \operatorname{mol}(\text { air })^{-1}$ & Farquhar et al. (1980) \\
\hline$K_{\mathrm{O}_{25}}$ & 0.33 & $\operatorname{mol}\left(\mathrm{O}_{2}\right) \operatorname{mol}(\text { air })^{-1}$ & Farquhar et al. (1980) \\
\hline$O_{i}$ & 0.21 & $\operatorname{mol}\left(\mathrm{O}_{2}\right) \operatorname{mol}(\text { air })^{-1}$ & Farquhar et al. (1980) \\
\hline$\Omega$ & 18 & ${ }^{\circ} \mathrm{C}$ & June et al. (2004) \\
\hline
\end{tabular}

et al., 2007; Oliveira et al., 1992). Although transpirational cooling of leaves should have been reduced due to limited stomatal conductance, the daily maximum leaf temperature $T_{1, \text { max }}$ increased by only $1.7^{\circ} \mathrm{C}$ in 2012 compared to 2011 (Sect. 3.2), so that temperature-based damage of enzymes relevant for photosynthesis is unlikely. The $\mathrm{CO}_{2}$ influx into the leaves was, however, heavily reduced under the drought conditions in 2012. Energy utilisation is thus limited, while incoming photosynthetically active radiation PAR in 2012 was comparably high to 2011 (see Sect. 3.1). It is therefore very likely that the main reason for the $Q$. suber trees down-regulating the maximum carboxylation rate $V_{\mathrm{c}, \max }$ by $43 \%$ (Fig. 7a) was to avoid over-excitation and photodamage (Demmig-Adams and Adams, 1992; Long et al., 1994; Werner et al., 2002). However, this effect may have been enforced by decreased nitrogen availability during the leaf development phase in late spring caused by reduced soil water and thus nitrogen solubility in 2012 (Fig. 5a and b), potentially changing leaf nitrogen status and permanently reducing photosynthetic capacity in 2012 compared to 2011 (Vaz et al., 2010). A possible indication of a permanent reduction in $V_{\mathrm{c}, \max }$ is that $g_{\mathrm{s}}$ tends to converge to the same value at the end of the drought period in both years (Fig. 7f), so that leaf-internal $\mathrm{CO}_{2}$ availability should have approached comparable values as well. $V_{\mathrm{c}, \max }$ remained, however, downregulated permanently. A simultaneous reduction in $V_{\mathrm{c}, \max }$ by $37 \%$ (Fig. 7a) and an increase in $m$ (9 or $29 \%$, depending on whether $g_{\mathrm{s}}$ was calculated following Ball et al. (1987) or Leuning (1995), Fig. 7b and c) were observed. In the case of a drought spell like 2012, the Q. suber trees responded with both, stomatal limitation as well as down-regulation of assimilation, strongly altering the entire ecosystem functioning, which was observed in different semi-arid ecosystems before (Reichstein et al., 2003; Egea et al., 2011; Zhou et al., 2013).
Fifth, the use of the Leuning (1995) model with variable $D_{0}$ allowed one to disentangle the different impacts on $g_{\mathrm{s}}$. Intra-annually, stomatal conductance showed a much stronger sensitivity to vpd (Fig. 7d) than to variations in assimilation (Fig. 7e). Between both years, $m /\left(1+\left(\overline{\mathrm{vpd}} / D_{0}\right)\right)$ increased only slightly, by $10 \%$, as a consequence of a slightly stronger reduction in $V_{\mathrm{c}, \max }$ than in $g_{\mathrm{s}}$ (43 and $37 \%$, respectively). This displays the strong resilience of sclerophyllous tree species like $Q$. suber to drought, maintaining a water use efficiency comparable to regular years (Zhou et al., 2013). The impact of vpd on $g_{\mathrm{s}}$ was, however, weakened in 2012 (reduction in $D_{0}$ by $37 \%$; not significant), since $g_{\mathrm{s}}$ was generally reduced at comparable vpd. $m$ compensated for fluctuations in $D_{0}$ (Fig. $7 \mathrm{~b}$ and d) to yield the observed robustness to assimilation. The observed high intraannual robustness indicates that these Mediterranean species are adapted to maintain a stable operational point (Werner and Máguas, 2010).

Sixth, all three model descriptions (cases 1-3) showed a decrease in the optimum temperature of photosynthesis $T_{\mathrm{opt}}$ by $4-8{ }^{\circ} \mathrm{C}$ from 2011 to 2012 (Fig. $7 \mathrm{~g}$ ). Leaf renewal in 2012 occurred under strong drought conditions due to the additional winter drought and under increased temperatures due to the bud burst occurring more than 1 month later than in 2011 (Costa e Silva et al., 2014), so carbon uptake in 2012 was further weakened due to a higher susceptibility of the photosynthesis apparatus to high temperatures in addition to the already discussed reduction in carboxylation efficiency $V_{\mathrm{c}, \max }$ by $43 \%$. Kattge and Knorr (2007) and von Caemmerer (2000), among others, showed, for different plant species, the opposite trend of increasing $T_{\mathrm{opt}}$ with increasing growth temperature. A possible explanation is that not only growth temperature but also nutrient availability and plant water status have changed strongly, here affecting thylakoid membrane properties more than growth temperature. 
In summary, the $Q$. suber trees responded to the drought year 2012 with a down-regulation of carboxylation efficiency and a decreased optimal temperature of photosynthesis. They counteracted this reduced carbon sequestration with a better responsiveness of the stomata. These plant responses were caused neither by a higher vapour pressure deficit, nor by leaf temperatures, nor by a depletion of upper soil moisture, but they were most probably triggered by a strong depletion of deep soil or groundwater due to the additional winter drought.

The combined model of photosynthesis and stomatal conductance was unable to reproduce the observed carbon assimilation and evapotranspiration if only one reaction was considered, i.e. either in the photosynthetic apparatus or in stomatal conductance. It needed to adapt parameters in both sub-modules, i.e. a strong reduction in carboxylation efficiency and a smaller increase in stomatal sensitivity. Earlier model-data approaches had shown that combined photosynthesis-stomatal conductance models need to adapt both parts in times of drought, but they always predicted decreases in carboxylation efficiency and stomatal sensitivity. However, the modelling performed here could not distinguish between different model formulations found in the literature, i.e. the stomatal conductance formulations of BallBerry vs. Leuning and the different formulations of optimal photosynthetic temperatures.

\subsection{Future development}

It is expected that the trend of decreasing total annual precipitation and alteration of precipitation patterns on the Iberian Peninsula, namely occurrences of additional winter/spring droughts, will continue with proceeding climate change (Bussotti et al., 2013; Guerreiro et al., 2013; Hulme et al., 1999). Such severe drought periods might occur at a higher frequency (Field et al., 2012; Heimann and Reichstein, 2008; Granier et al., 2007; Miranda et al., 2002), thereby affecting the ecosystem water balance and productivity (Chaves et al., 2002; Fischer et al., 2002). If precipitation patterns similar to 2012 occur more often, then a sustainable depletion of local groundwater reservoirs as well as water storage basins might be expected. This will strongly affect local agriculture that relies on groundwater for the deep-rooted cork-oak trees and otherwise uses irrigation water from storage basins. The soil seed bank of native understorey plants may also deplete in the long term due to a shorter life cycle and reduced seed formation (Jongen et al., 2013c; Peñuelas et al., 2002, 2004; Gordo and Sanz, 2005). A shift in species composition is likely (de Dios Miranda et al., 2009), but could not be observed in this ecosystem in a study by Dubbert et al. (2014a, 2012 data not shown) during the drought year 2012 itself. However, some effects such as tree mortality may only be evident in the long term after multiple, consecutive drought years (David et al., 2004; Bussotti et al., 2013).

\section{Conclusions}

We reported on the ecosystem fluxes of a savannah-type cork-oak woodland under extreme hydrological conditions and altered precipitation $P$ patterns. We analysed the effects of drought in the year 2012 compared to the wet year 2011 on evapotranspiration and gross primary productivity of a montado ecosystem and its overstorey and understorey components. We additionally analysed physiological reactions of the $Q$. suber trees.

We conclude with the following results: (1) the precipitation effectiveness $\mathrm{ET}_{\mathrm{o}} / P$ increased up to $122 \%$ in the 2012 dry year, possible due to the groundwater access of $Q$. suber trees leaving no water for groundwater replenishing and runoff generation. If trends of decreasing annual $P$ continue, sustainable effects on local groundwater reservoirs and storage basins may be expected. (2) The understorey gross primary productivity $\mathrm{GPP}_{\mathrm{u}}$ and the overstorey gross primary productivity $\mathrm{GPP}_{\mathrm{o}}$ were reduced by 53 and $28 \%$, respectively, in 2012 compared to 2011, due to a late onset of 2011 autumn rains and an additional severe winter/spring drought. Long-term changes in understorey species composition and tree productivity are likely if prolonged summer droughts and additional winter/spring droughts become more frequent. (3) A combined photosynthesis and stomatal conductance model worked best if it was able to adapt the apparent maximum carboxylation rate $V_{\mathrm{c}, \max }$ and the stomatal conductance parameters simultaneously. The slope $m$ of the stomatal conductance model had to be increased to compensate partly for the strong decrease in the carboxylation rate. The model also adjusted the sensitivity of the stomata $D_{0}$ to vapour pressure deficit vpd in the Leuning model, because both stomatal parameters, $m$ and $D_{0}$, are strongly correlated. The model performance was similar to the Ball-Berry approach. (4) The combined photosynthesis and stomatal conductance model also adjusted the optimum temperature of electron transport $T_{\mathrm{opt}}$ to lower values. This decreases carbon sequestration under higher temperatures, but also makes the photosynthetic apparatus more vulnerable to heat stress in dry years. (5) The ecosystem was a carbon sink in both years, with a $38 \%$ reduced sink strength in the 2012 dry year compared to 2011 . Gross primary productivity GPP was thereby a much stronger driver than ecosystem respiration $R_{\text {eco }}$ of the inter-annual variations of the carbon sink. 


\section{Appendix A: Photosynthesis-stomatal conductance model}

The entire canopy was separated into a sunlit and shaded part with the fraction of sunlit leaves as

$f_{\mathrm{s}}=\frac{1-\exp (-K \mathrm{LAI})}{K \mathrm{LAI}}$,

where LAI $\left(\mathrm{m}_{\text {leaf }}^{2} \mathrm{~m}_{\text {ground }}^{-2}\right)$ is the leaf area index and $K=$ $G(\beta) / \cos (\beta)$, with $G$ being the angular-dependent leaf projection function and $\beta\left(^{\circ}\right)$ being the sun zenith angle. The shaded fraction of the canopy equals $\left(1-f_{\mathrm{s}}\right)$. Carbon assimilation $A\left(\operatorname{mol}\left(\mathrm{CO}_{2}\right) \mathrm{m}^{-2} \mathrm{~s}^{-1}\right)$ was modelled for each fraction with the Farquhar et al. (1980) model in the form of Knorr (2000) and enhanced by a smooth minimum function smin:

$A=\operatorname{smin}\left\{J_{\mathrm{C}} ; J_{\mathrm{E}} ; \eta\right\}-R_{\mathrm{d}}$

with the carboxylation-limited rate $J_{\mathrm{C}}\left(\operatorname{mol}\left(\mathrm{CO}_{2}\right) \mathrm{m}^{-2} \mathrm{~s}^{-1}\right)$, the electron transport-limited rate $J_{\mathrm{E}}\left(\mathrm{mol}\left(\mathrm{CO}_{2}\right) \mathrm{m}^{-2} \mathrm{~s}^{-1}\right)$ and mitochondrial respiration $R_{\mathrm{d}}\left(\operatorname{mol}\left(\mathrm{CO}_{2}\right) \mathrm{m}^{-2} \mathrm{~s}^{-1}\right)$. The smoothing parameter $\eta$ was set to 0.9 . The Rubisco-limited rate $J_{\mathrm{C}}$ was described by

$$
J_{\mathrm{C}}=V_{\mathrm{c}, \max } \frac{C_{\mathrm{i}}-\Gamma_{\star}}{C_{\mathrm{i}}+K_{\mathrm{C}}\left(1+\left(\frac{O_{i}}{K_{\mathrm{O}}}\right)\right)},
$$

with maximum carboxylation rate $V_{\mathrm{c}, \max }$ $\left(\mathrm{mol}\left(\mathrm{CO}_{2}\right) \mathrm{m}^{-2} \mathrm{~s}^{-1}\right), \quad \mathrm{CO}_{2}$ concentration inside the stomatal cavity $C_{\mathrm{i}}\left(\operatorname{mol}\left(\mathrm{CO}_{2}\right) \operatorname{mol}(\text { air })^{-1}\right), \mathrm{CO}_{2}$ compensation point $\Gamma_{\star}\left(\operatorname{mol}\left(\mathrm{CO}_{2}\right) \operatorname{mol}(\text { air })^{-1}\right)$ (set to leaf temperature $\left.T_{1} \times 1.7 \times 10^{-6}\right)$, and Michaelis-Menten constants for $\mathrm{CO}_{2} K_{\mathrm{C}}\left(\operatorname{mol}\left(\mathrm{CO}_{2}\right) \operatorname{mol}(\text { air })^{-1}\right)$ and $\mathrm{O}_{2} K_{\mathrm{O}}$ $\left(\operatorname{mol}\left(\mathrm{O}_{2}\right) \operatorname{mol}(\text { air })^{-1}\right)$, respectively. $O_{i}\left(\operatorname{mol}\left(\mathrm{O}_{2}\right) \operatorname{mol}(\text { air })^{-1}\right)$ is the stomatal cavity $\mathrm{O}_{2}$ concentration taken as $21 \%$. The RuBP-limited $\mathrm{CO}_{2}$ assimilation rate $J_{\mathrm{E}}$ was described by

$J_{\mathrm{E}}=J \frac{C_{\mathrm{i}}-\Gamma_{\star}}{4\left(C_{\mathrm{i}}+2 \Gamma_{\star}\right)}$,

with the rate of electron transport $J\left(\mathrm{molm}^{-2} \mathrm{~s}^{-1}\right)$ as

$J=J_{\max } \frac{\alpha \mathrm{PAR}}{\sqrt{J_{\max }^{2}+\alpha^{2} \mathrm{PAR}^{2}}}$,

with maximum electron transport rate $J_{\max }$ $\left(\operatorname{mol}\left(\mathrm{CO}_{2}\right) \mathrm{m}^{-2} \mathrm{~s}^{-1}\right)$, quantum yield of electron transport $\alpha$ and incident photosynthetically active photon flux density PAR (mol(quanta) $\mathrm{m}^{-2} \mathrm{~s}^{-1}$ ). The sunlit fraction of leaves $f_{\mathrm{s}}$ receives direct as well as diffuse incoming radiation, whereas the shaded fraction of leaves $\left(1-f_{\mathrm{s}}\right)$ only receives diffuse radiation. The temperature dependencies of $K_{\mathrm{C}}, K_{\mathrm{O}}$ and $R_{\mathrm{d}}$ were modelled using Arrhenius functions:

$f\left(T_{1}\right)=K_{25} \exp \left(\frac{E_{K}\left(T_{1}-25\right)}{298 R\left(T_{1}+273\right)}\right)$, with the base rates $K_{\mathrm{C}_{25}}\left(\operatorname{mol}\left(\mathrm{CO}_{2}\right) \operatorname{mol}(\text { air })^{-1}\right), K_{\mathrm{O}_{25}}$ $\left(\operatorname{mol}\left(\mathrm{O}_{2}\right) \operatorname{mol}(\text { air })^{-1}\right), \operatorname{Rd}_{25}\left(\operatorname{mol}\left(\mathrm{CO}_{2}\right) \mathrm{m}^{-2} \mathrm{~s}^{-1}\right)$ at $25^{\circ} \mathrm{C}$ and activation energies $E_{\mathrm{C}}, E_{\mathrm{O}}$, and $E_{\mathrm{Rd}}\left(\mathrm{J} \mathrm{mol}^{-1}\right)$, respectively. $T_{1}\left({ }^{\circ} \mathrm{C}\right)$ is leaf temperature and $R\left(\mathrm{~J} \mathrm{~mol}^{-1} \mathrm{~K}^{-1}\right)$ is the universal gas constant.

Temperature dependencies of $V_{\mathrm{c}, \max }$ and $J_{\max }$ were treated by three test cases with decreasing complexity and computational demand. Case 1, according to Medlyn et al. (2002) and Kattge and Knorr (2007): $V_{c, \max }$ and $J_{\max }$ were both modelled using a modification of the Arrhenius function (Eq. A6) showing a peak at optimum temperature followed by a decline with increasing $T_{1}$ :

$$
\begin{gathered}
f\left(T_{1}\right)=K_{\max 25} \exp \left(\frac{E_{K}\left(T_{1}-25\right)}{298 R\left(T_{1}+273\right)}\right) \\
\frac{1+\exp \left(\frac{298 \Delta S_{K}-\mathrm{Hd}_{K}}{298 R}\right)}{1+\exp \left(\frac{\left(T_{1}+273\right) \Delta S_{K}-\mathrm{Hd}_{K}}{\left(T_{1}+273\right) R}\right)},
\end{gathered}
$$

with base rates $V_{\mathrm{c}, \max 25}$ and $J_{\max 25}$ at $25^{\circ} \mathrm{C}$, respectively. $\Delta S_{V}$ and $\Delta S_{J}\left(\mathrm{~J} \mathrm{~mol}^{-1} \mathrm{~K}^{-1}\right)$ are the entropy factors and $\mathrm{Hd}_{V}$ and $\mathrm{Hd}_{J}\left(\mathrm{~J} \mathrm{~mol}^{-1}\right)$ are the deactivation energies of $V_{\mathrm{c}, \max }$ and $J_{\max }$, respectively. Case 2 , according to von Caemmerer (2000): only the temperature dependency of $J_{\max }$ was modelled with the peaked function (Eq. A7), but $V_{\mathrm{c}, \max }$ was modelled with the simple Arrhenius function (Eq. A6). Case 3, according to June et al. (2004): $V_{\mathrm{c}, \max }$ was modelled with the simple Arrhenius function, but $J_{\max }$ was modelled with a simple Gaussian temperature dependency:

$$
\begin{aligned}
J_{\max } & =J_{\mathrm{opt}} \exp \left(-\frac{\left(T_{1}-T_{\mathrm{opt}}\right)^{2}}{\Omega^{2}}\right) \\
& =J_{\max 25} \exp \left(\frac{\left(25-T_{\mathrm{opt}}\right)^{2}-\left(T_{1}-T_{\mathrm{opt}}\right)^{2}}{\Omega^{2}}\right),
\end{aligned}
$$

with optimum temperature $T_{\mathrm{opt}}\left({ }^{\circ} \mathrm{C}\right)$ and the empirical parameter $\Omega=18^{\circ} \mathrm{C}$.

Leaf surface $\quad \mathrm{CO}_{2} \quad$ concentration $C_{\mathrm{s}}$ $\left(\operatorname{mol}\left(\mathrm{CO}_{2}\right) \operatorname{mol}(\text { air })^{-1}\right)$ and $\mathrm{H}_{2} \mathrm{O}$ concentration $W_{\mathrm{s}}$ $\left(\operatorname{mol}\left(\mathrm{H}_{2} \mathrm{O}\right) \operatorname{mol}(\text { air })^{-1}\right)$ were calculated via

$C_{\mathrm{s}}=C_{\mathrm{a}}-A\left(\frac{1}{g_{\mathrm{a}}}+\frac{1.3}{g_{\mathrm{b}}}\right)$

$W_{\mathrm{s}}=W_{\mathrm{a}}-\mathrm{ET}_{\bmod }\left(\frac{1}{g_{\mathrm{a}}}+\frac{1}{g_{\mathrm{b}}}\right)$

with the atmospheric $\mathrm{CO}_{2}$ concentration $C_{\mathrm{a}}$ $\left(\operatorname{mol}\left(\mathrm{CO}_{2}\right) \operatorname{mol}(\text { air })^{-1}\right)$, aerodynamic conductance $g_{\mathrm{a}}$ (mol(air) $\mathrm{m}^{-2} \mathrm{~s}^{-1}$ ), leaf boundary layer conductance $g_{\mathrm{b}}$ (mol(air) $\mathrm{m}^{-2} \mathrm{~s}^{-1}$ ), atmospheric $\mathrm{H}_{2} \mathrm{O}$ concentration $W_{\mathrm{a}}$ $\left(\operatorname{mol}\left(\mathrm{H}_{2} \mathrm{O}\right) \operatorname{mol}(\text { air })^{-1}\right)$, modelled transpiration $\mathrm{ET}_{\bmod }$ $\left(\mathrm{mol}\left(\mathrm{H}_{2} \mathrm{O}\right) \mathrm{m}^{-2} \mathrm{~s}^{-1}\right)$ and stomatal conductance for water vapour $g_{\mathrm{s}, \mathrm{h}}\left(\operatorname{mol}\left(\mathrm{H}_{2} \mathrm{O}\right) \mathrm{m}^{-2} \mathrm{~s}^{-1}\right) . g_{\mathrm{a}}$ was measured (see Sect. 2.6) and $g_{\mathrm{b}}$ was estimated with the approach of Bonan 
(2002) via $g_{\mathrm{b}}=200 \sqrt{d / u}$, where $d$ is the measured leaf size and $u$ is the observed wind speed.

Stomatal conductance for water vapour $g_{\mathrm{s}, \mathrm{h}}$ was calculated with the formulation of Leuning (1995):

$g_{\mathrm{s}, \mathrm{h}}=m \frac{A}{\left(C_{\mathrm{s}}-\Gamma_{\star}\right)\left(1+\frac{W_{i}-W_{\mathrm{s}}}{D_{0}}\right)}+b$,

with the slope $m \quad\left(\operatorname{mol}\left(\mathrm{H}_{2} \mathrm{O}\right) \operatorname{mol}(\mathrm{air})^{-1}\right)$, the sensitivity parameter of vapour pressure deficit $D_{0} \quad\left(\operatorname{mol}\left(\mathrm{H}_{2} \mathrm{O}\right) \operatorname{mol}(\mathrm{air})^{-1}\right)$ and the offset $b$ $\left(\mathrm{mol}\left(\mathrm{H}_{2} \mathrm{O}\right) \mathrm{m}^{-2} \mathrm{~s}^{-1}\right)$. The description of Ball et al. (1987) was also tested:

$g_{\mathrm{s}, \mathrm{h}}=m \frac{A \mathrm{rH}_{\mathrm{s}}}{C_{\mathrm{s}}}+b$

with relative humidity at the leaf surface $\mathrm{rH}_{\mathrm{s}}(-)$. Total conductances for $\mathrm{CO}_{2} g_{\mathrm{c}, \mathrm{c}}$ and $\mathrm{H}_{2} \mathrm{O} g_{\mathrm{c}, \mathrm{h}}$ were then derived by

$g_{\mathrm{c}, \mathrm{c}}=\frac{1}{\left(\frac{1.56}{g_{\mathrm{s}, \mathrm{h}}}+\frac{1}{g_{\mathrm{a}}}+\frac{1.3}{g_{\mathrm{b}}}\right)}$

$g_{\mathrm{c}, \mathrm{h}}=\frac{1}{\left(\frac{1}{g_{\mathrm{s}, \mathrm{h}}}+\frac{1}{g_{\mathrm{a}}}+\frac{1}{g_{\mathrm{b}}}\right)}$.

$\mathrm{CO}_{2}$ concentration in the stomatal cavity was thus calculated by

$C_{\mathrm{i}}=C_{\mathrm{a}}-\frac{A}{g_{\mathrm{c}, \mathrm{c}}}$, and modelled transpiration $\mathrm{ET}_{\bmod }\left(\operatorname{mol}\left(\mathrm{H}_{2} \mathrm{O}\right) \mathrm{m}^{-2} \mathrm{~s}^{-1}\right)$ and gross primary productivity $\mathrm{GPP}_{\text {mod }}\left(\operatorname{mol}\left(\mathrm{CO}_{2}\right) \mathrm{m}^{-2} \mathrm{~s}^{-1}\right)$ for both, the sunlit and shaded fractions of the canopy, could be derived by

$\mathrm{ET}_{\text {mod }}=g_{\mathrm{c}, \mathrm{h}}\left(W_{i}-W_{\mathrm{a}}\right)$
$\mathrm{GPP}_{\text {mod }}=g_{\mathrm{c}, \mathrm{c}}\left(C_{\mathrm{a}}-C_{\mathrm{i}}\right)+R_{\mathrm{d}}$.

The optimum temperature $T_{\mathrm{opt}}$ of the maximum electron transport rate $J_{\max }$ was calculated in cases 1 and 2 according to von Caemmerer (2000):

$$
T_{\mathrm{opt}}=\frac{\mathrm{Hd}_{J}}{\Delta S_{J}-R \log \left(\frac{E_{J_{\max }}}{\operatorname{Hd}_{J}-E_{J_{\max }}}\right)}-273.15 .
$$

The entire calculation was iterated with initial values of $\mathrm{ET}_{\text {mod }}=0, g_{\mathrm{s}, \mathrm{h}}=1$ and $C_{\mathrm{i}}=0.8 C_{\mathrm{a}}$, until a conversion of $C_{\mathrm{i}}$ was achieved for every time step. The modelled $\mathrm{ET}_{\text {mod }}$ and GPP $_{\text {mod }}$ of the sunlit and shaded parts of the canopy were averaged using $f_{\mathrm{s}}$ and fitted against measured ET and GPP under variation of $V_{\mathrm{c}, \max 25}, \Delta S_{J}, m$ and $D_{0}$. Constant relationships of $J_{\max 25}=1.67 V_{\mathrm{c}, \max 25}$ and $\mathrm{Rd}_{25}=0.011 V_{\mathrm{c}, \max 25}$ were assumed (Medlyn et al., 2002; Kattge and Knorr, 2007). All other parameters used can be found in Table 1. 


\section{Appendix B: Nomenclature}

\begin{tabular}{|c|c|c|}
\hline$A$ & $\left(\mathrm{molm}^{-2} \mathrm{~s}^{-1}\right)$ & Carbon assimilation \\
\hline$b$ & $\left(\mathrm{molH}_{2} \mathrm{Om}^{-2} \mathrm{~s}^{-1}\right)$ & Leuning model parameter (offset) \\
\hline$D_{0}$ & $(\mathrm{hPa})$ & Leuning model parameter (vpd sensitivity) \\
\hline $\mathrm{ET}_{\mathrm{O}}$ & $\left(\mathrm{mmd}^{-1}\right)$ & Evapotranspiration measured at the overstorey tower \\
\hline $\mathrm{ET}_{\mathrm{u}}$ & $\left(\mathrm{mmd}^{-1}\right)$ & Evapotranspiration measured at the understorey tower \\
\hline $\mathrm{ET}_{\mathrm{o}} / P$ & $(\%)$ & Precipitation effectiveness \\
\hline$\overline{\varepsilon_{\mathrm{GPP}_{\mathrm{o}}}}$ & $(-)$ & Average Nash-Sutcliffe model efficiency for $\mathrm{GPP}_{0}$ \\
\hline$\overline{\varepsilon_{\mathrm{ET}_{\mathrm{o}}}}$ & $(-)$ & Average Nash-Sutcliffe model efficiency for $\mathrm{ET}_{\mathrm{O}}$ \\
\hline$f_{\mathrm{s}}$ & $(-)$ & Fraction of sunlit leaves \\
\hline GPP & $\left(\mathrm{gCm}^{-2} \mathrm{~d}^{-1}\right)$ & Gross primary productivity \\
\hline $\mathrm{GPP}_{\mathrm{o}}$ & $\left(\mathrm{gCm}^{-2} \mathrm{~d}^{-1}\right)$ & $\begin{array}{l}\text { Gross primary productivity measured at the overstorey } \\
\text { tower }\end{array}$ \\
\hline $\mathrm{GPP}_{\mathrm{u}}$ & $\left(\mathrm{gCm}^{-2} \mathrm{~d}^{-1}\right)$ & $\begin{array}{l}\text { Gross primary productivity measured at the under- } \\
\text { storey tower }\end{array}$ \\
\hline$g_{\mathrm{s}, \mathrm{h}}$ & $\left(\mathrm{molH}_{2} \mathrm{Om}^{-2} \mathrm{~s}^{-1}\right)$ & Stomatal conductance for water vapour \\
\hline$g_{\mathrm{s}, \mathrm{c}}$ & $\left(\mathrm{molCO}_{2} \mathrm{~m}^{-2} \mathrm{~s}^{-1}\right)$ & Stomatal conductance for carbon \\
\hline LAI & $\left(\mathrm{m}_{\text {leaf }}^{2} \mathrm{~m}_{\text {ground }}^{-2}\right)$ & Leaf area index \\
\hline$m$ & $\left(\mathrm{molH}_{2} \mathrm{O} \mathrm{mol} \mathrm{air}^{-1}\right)$ & Leuning model parameter (slope) \\
\hline NEE & $\left(\mathrm{gCm}^{-2} \mathrm{~d}^{-1}\right)$ & Net ecosystem carbon exchange \\
\hline $\mathrm{NEE}_{\mathrm{O}}$ & $\left(\mathrm{gCm}^{-2} \mathrm{~d}^{-1}\right)$ & $\begin{array}{l}\text { Net ecosystem carbon exchange measured at the over- } \\
\text { storey tower }\end{array}$ \\
\hline $\mathrm{NEE}_{\mathrm{u}}$ & $\left(\mathrm{gCm}^{-2} \mathrm{~d}^{-1}\right)$ & Understorey and soil net carbon exchange \\
\hline$P$ & $(\mathrm{~mm})$ & Precipitation \\
\hline$p$ & $(\mathrm{hPa})$ & Atmospheric pressure \\
\hline PAR & $\left(\mu \mathrm{molm} \mathrm{m}^{-2} \mathrm{~s}^{-1}\right)$ & Photosynthetically active radiation \\
\hline$P_{\text {gap }}$ & $(-)$ & Tree canopy gap probability \\
\hline$R_{\text {eco }}$ & $\left(\mathrm{gCm}^{-2} \mathrm{~d}^{-1}\right)$ & Ecosystem respiration \\
\hline $\mathrm{rH}$ & $(\%)$ & Relative air humidity \\
\hline $\mathrm{rH}_{\mathrm{S}}$ & $(\%)$ & Relative air humidity at the leaf surface \\
\hline$\theta$ & $(\%)$ & Soil moisture \\
\hline$T$ & $\left(\mathrm{mmd}^{-1}\right)$ & Transpiration \\
\hline$T_{\mathrm{a}}$ & $\left({ }^{\circ} \mathrm{C}\right)$ & Air temperature \\
\hline$T_{1}$ & $\left({ }^{\circ} \mathrm{C}\right)$ & Leaf temperature \\
\hline$T_{1, \max }$ & $\left({ }^{\circ} \mathrm{C}\right)$ & Maximum daily leaf temperature \\
\hline$T_{\text {opt }}$ & $\left({ }^{\circ} \mathrm{C}\right)$ & Optimum temperature of electron transport \\
\hline$T_{\mathrm{S}}$ & $\left({ }^{\circ} \mathrm{C}\right)$ & Soil temperature \\
\hline$V_{\mathrm{c}, \max }$ & $\left(\mu \mathrm{molm} \mathrm{m}^{-2} \mathrm{~s}^{-1}\right)$ & Apparent maximum carboxylation rate \\
\hline vpd & $(\mathrm{hPa})$ & Air vapour pressure deficit \\
\hline $\operatorname{vpd}_{\max }$ & $(\mathrm{hPa})$ & Maximum daily air vapour pressure deficit \\
\hline
\end{tabular}


Acknowledgements. We thank the Herdade da Machoqueira do Grou the permission to establish our field site. We thank Tino Rau for providing data processing code and Sebastian Gimper for technical support. We thank Juliane Mai for help with mathematics. We thank Joaquim Pinto for information on meteorology. This study was funded by the Deutsche Forschungsgemeinschaft (WATERFLUX project: WE 2681-61; CU 173/2-1) and kindly supported by the Helmholtz Impulse and Networking Fund through the Helmholtz Interdisciplinary Graduate School for Environmental Research (HIGRADE) (Bissinger and Kolditz, 2008).

The service charges for this open-access publication have been covered by a Research Centre of the Helmholtz Association.

Edited by: J. Xiao

\section{References}

Aubinet, M., Grelle, A., Ibrom, A., Rannik, Ü., Moncrieff, J., Foken, T., Kowalski, A., Martin, P., Berbigier, P., Bernhofer, C., Clement, R., Elbers, J., Granier, A., Grünwald, T., Morgenstern, K., Pilegaard, K., Rebmann, C., Snijders, W., Valentini, R., and Vesala, T.: Estimates of the Annual Net Carbon and Water Exchange of Forests: The EUROFLUX Methodology, vol. 30 of Adv. Ecol. Res., Academic Press, 113-175, doi:10.1016/S00652504(08)60018-5, 1999.

Baldocchi, D. D., Ma, S., Rambal, S., Misson, L., Ourcival, J.-M., Limousin, J.-M., Pereira, J., and Papale, D.: On the differential advantages of evergreenness and deciduousness in mediterranean oak woodlands: a flux perspective, Ecol. Appl., 20, 1583-1597, doi:10.1890/08-2047.1, 2009.

Ball, J., Woodrow, L. E., and Beny, J. A.: A model predicting stomatal conductance and its contribution to the control of photosynthesis under different environmental conditions, in: Progress in Photosynthesis Research, edited by: Biggins, J., vol. 4, Nijhoff, Dordrecht, 221-224, 1987.

Beer, C., Reichstein, M., Tomelleri, E., Ciais, P., Jung, M., Carvalhais, N., Rödenbeck, C., Arain, M. A., Baldocchi, D., Bonan, G. B., Bondeau, A., Cescatti, A., Lasslop, G., Lindroth, A., Lomas, M., Luyssaert, S., Margolis, H., Oleson, K. W., Roupsard, O., Veenendaal, E., Viovy, N., Williams, C., Woodward, F. I., and Papale, D.: Terrestrial gross carbon dioxide uptake: global distribution and covariation with climate, Science, 329, 834-838, doi:10.1126/science.1184984, 2010.

Beerling, D. and Quick, W.: A new technique for estimating rates of carboxylation and electron transport in leaves of $\mathrm{C}_{3}$ plants for use in dynamic global vegetation models, Glob. Change Biol., 1, 289-294, doi:10.1111/j.1365-2486.1995.tb00027.x, 1995.

Berry, J. and Björkman, O.: Photosynthetic response and adaptation to temperature in higher plants, Ann. Rev. Plant Physio., 31, 491543, doi:10.1146/annurev.pp.31.060180.002423, 1980.

Besson, C. K., do Vale, R. L., Rodrigues, M. L., Almeida, P., Herd, A., Grant, O. M., David, T. S., Schmidt, M., Otieno, D., Keenan, T. F., Gouveia, C., Mériaux, C., Chaves, M. M., and Pereira, J. S.: Cork oak physiological responses to manipulated water availability in a Mediterranean woodland, Agr. Forest
Meteorol., 184, 230-242, doi:10.1016/j.agrformet.2013.10.004, 2014.

Beyschlag, W., Lange, O., and Tenhunen, J. D.: Photosynthesis and water relations of the mediterranean evergreen sclerophyll Arbutus unedo L. throughout the year at a site in Portugal. I. diurnal courses of carbon dioxide gas exchange and transpiration under natural conditions, Flora, 178, 409-444, 1986.

Bissinger, V. and Kolditz, O.: Helmholtz Interdisciplinary Graduate School for Environmental Research (HIGRADE), GAIA, 1, 7173, 2008.

Bonan, G. B.: Ecological Climatology: Concepts and Applications, Cambridge University Press, 2002.

Bugalho, M. N., Caldeira, M. C., Pereira, J. S., Aronson, J., and Pausas, J. G.: Mediterranean cork oak savannas require human use to sustain biodiversity and ecosystem services, Front. Ecol. Environ., 9, 278-286, doi:10.1890/100084, 2011.

Bussotti, F., Ferrini, F., Pollastrini, M., and Fini, A.: The challenge of Mediterranean sclerophyllous vegetation under climate change: from acclimation to adaptation, Environ. Exp. Bot., 103, 80-98, doi:10.1016/j.envexpbot.2013.09.013, 2013.

Chaves, M. M., Pereira, J. S., Maroco, J., Rodrigues, M. L., Ricardo, C. P. P., Osório, M. L., Catvalho, I., Faria, T., and Pinheiro, C.: How plants cope with water stress in the field? Photosynthesis and growth, Ann. Bot.-London, 89, 907-916, doi:10.1093/aob/mcf105, 2002.

Ciais, P., Reichstein, M., Viovy, N., Granier, A., Ogee, J., Allard, V., Aubinet, M., Buchmann, N., Bernhofer, C., Carrara, A., Chevallier, F., De Noblet, N., Friend, A. D., Friedlingstein, P., Grunwald, T., Heinesch, B., Keronen, P., Knohl, A., Krinner, G., Loustau, D., Manca, G., Matteucci, G., Miglietta, F., Ourcival, J. M., Papale, D., Pilegaard, K., Rambal, S., Seufert, G., Soussana, J. F., Sanz, M. J., Schulze, E. D., Vesala, T., and Valentini, R.: Europe-wide reduction in primary productivity caused by the heat and drought in 2003, Nature, 437, 529-533, doi:10.1038/nature03972, 2005.

Collatz, G. J., Ribas-Carbo, M., and Berry, J. A.: Coupled photosynthesis-stomatal conductance model for leaves of $\mathrm{C}_{4}$ plants, Aust. J. Plant Physiol., 19, 519-538, doi:10.1071/PP9920519, 1992.

Costa, A. C., Santos, J. A., and Pinto, J. G.: Climate change scenarios for precipitation extremes in Portugal, Theor. Appl. Climatol., 108, 217-234, doi:10.1007/s00704-011-0528-3, 2012.

Costa e Silva, F., Correia, A. C., Correia, A. V., Piayda, A., Dubbert, M., Werner, C., David, J. S., and Pereira, J. S.: Quercus suber phenological adjustments to seasonal water availability: influence on net ecosystem exchange, Agr. Forest Meteorol., submitted, 2014.

Cowan, I.: Stomatal Behaviour and Environment, Academic Press, available at: http://books.google.com.au/books?id= GYhvNQAACAAJ (last access: 1 July 2014), 1977.

Damour, G., Simonneau, T., Cochard, H., and Urban, L.: An overview of models of stomatal conductance at the leaf level, Plant Cell Environ., 33, 1419-1438, doi:10.1111/j.13653040.2010.02181.x, 2010.

David, T., Ferreira, M., Cohen, S., Pereira, J., and David, J.: Constraints on transpiration from an evergreen oak tree in southern Portugal, Agr. Forest Meteorol., 122, 193-205, doi:10.1016/j.agrformet.2003.09.014, 2004. 
David, T. S., Henriques, M. O., Kurz-Besson, C., Nunes, J., Valente, F., Vaz, M., Pereira, J. S., Siegwolf, R., Chaves, M. M., Gazarini, L. C., and David, J. S.: Water-use strategies in two co-occurring Mediterranean evergreen oaks: surviving the summer drought, Tree Physiol., 27, 793-803, doi:10.1093/treephys/27.6.793, 2007.

de Dios Miranda, J., Padilla, F. M., and Pugnaire, F. I.: Response of a Mediterranean semiarid community to changing patterns of water supply, Perspect. Plant Ecol., 11, 255-266, doi:10.1016/j.ppees.2009.05.001, 2009.

Demmig-Adams, B. and Adams, W. W.: Photoprotection and other responses of plants to high light stress, Ann. Rev. Plant Biol., 43, 599-626, 1992.

De Pury, D. G. G. and Farquhar, G. D.: Simple scaling of photosynthesis from leaves to canopies without the errors of big-leaf models, Plant Cell Environ., 20, 537-557, doi:10.1111/j.13653040.1997.00094.x, 1997.

Dubbert, M., Mosena, A., Piayda, A., Cuntz, M., Correia, A., Pereira, J. S., and Werner, C.: Influence of tree cover on herbaceous layer development and fluxes in a Portuguese cork oak woodland, Acta Oecol., 59, 35-45, 2014a.

Dubbert, M., Piayda, A., Cuntz, M., Correia, A. C., Costa e Silva, F., Pereira, J. S., and Werner, C.: Stable oxygen isotope and flux partitioning d emonstrates understory of an oak savanna contributes up to half of ecosystem carbon and water exchange, Frontiers in Plant Science, 5, 1-16, doi:10.3389/fpls.2014.00530, 2014b.

Duckstein, L.: Multiobjective optimization in structural design: the model choice problem, in: New Directions in Optimum Structural Design, edited by: Atrek, E., John Wiley, 1981.

Egea, G., Verhoef, A., and Vidale, P. L.: Towards an improved and more flexible representation of water stress in coupled photosynthesis-stomatal conductance models, Agr. Forest Meteorol., 151, 1370-1384, doi:10.1016/j.agrformet.2011.05.019, 2011

Ehleringer, J. R. and Cook, C. S.: Photosynthesis in encelia farinosa gray in response to decreasing leaf water potential, Plant Physiol., 75, 688-693, doi:10.1104/pp.75.3.688, 1984.

Espigares, T. and Peco, B.: Mediterranean pasture dynamics: the role of germination, J. Veg. Sci., 4, 189-194, 1993.

Espigares, T. and Peco, B.: Mediterranean annual pasture dynamics: impact of autumn drought, J. Ecol., 83, 135-142, 1995.

Eugster, W. and Senn, W.: A cospectral correction model for measurement of turbulent $\mathrm{NO}_{2}$ flux, Bound.-Lay. Meteorol., 74, 321340, doi:10.1007/BF00712375, 1995.

Farquhar, G., Caemmerer, S., and Berry, J.: A biochemical model of photosynthetic $\mathrm{CO}_{2}$ assimilation in leaves of $\mathrm{C}_{3}$ species, Planta, 149, 78-90, doi:10.1007/BF00386231, 1980.

Farquhar, G. D. and Sharkey, T. D.: Stomatal conductance and photosynthesis, Ann. Rev. Plant Physio., 33, 317-345, doi:10.1146/annurev.pp.33.060182.001533, 1982.

Field, C., Barros, V., Stocker, T., Qin, D., Dokken, D., Ebi, K., Mastrandrea, M., Mach, K., Plattner, G.-K., Allen, S., Tignor, M., and Midgley, P. (Eds.): Managing the Risks of Extreme Events and Disasters to Advance Climate Change Adaptation, IPCC Special Reports, Cambridge University Press, Cambridge, available at: https:/www.ipcc.ch/pdf/special-reports/ srex/SREX_Full_Report.pdf, 2012.

Figueroa, M. E. and Davy, A. J.: Response of Mediterranean grassland species to changing rainfall, J. Ecol., 79, 925-941, 1991.
Fischer, G., van Velthuizen, H., Shah, M., and Nachtergaele, F. (Eds.): Global Agro-ecological Assessment for Agriculture in the 21st Century: Methodology and Results, International Institute for Applied Systems Analysis, 2002.

Foken, T.: The energy balance closure problem: an overview, Ecol. Appl., 18, 1351-1367, doi:10.1890/06-0922.1, 2008.

Foken, T. and Wichura, B.: Tools for quality assessment of surfacebased flux measurements, Agr. Forest Meteorol., 78, 83-105, doi:10.1016/0168-1923(95)02248-1, 1996.

García-Barrón, L., Morales, J., and Sousa, A.: Characterisation of the intra-annual rainfall and its evolution (1837-2010) in the southwest of the Iberian Peninsula, Theor. Appl. Climatol., 114, 445-457, doi:10.1007/s00704-013-0855-7, 2013.

Gordo, O. and Sanz, J. J.: Phenology and climate change: a longterm study in a Mediterranean locality, Oecologia, 146, 484-495, doi:10.1007/s00442-005-0240-z, 2005.

Grace, J., José, J. S., Meir, P., Miranda, H. S., and Montes, R. A.: Productivity and carbon fluxes of tropical savannas, J. Biogeogr., 33, 387-400, doi:10.1111/j.1365-2699.2005.01448.x, 2006.

Granier, A., Reichstein, M., Bréda, N., Janssens, I., Falge, E., Ciais, P., Grünwald, T., Aubinet, M., Berbigier, P., Bernhofer, C., Buchmann, N., Facini, O., Grassi, G., Heinesch, B., Ilvesniemi, H., Keronen, P., Knohl, A., Köstner, B., Lagergren, F., Lindroth, A., Longdoz, B., Loustau, D., Mateus, J., Montagnani, L., Nys, C., Moors, E., Papale, D., Peiffer, M., Pilegaard, K., Pita, G., Pumpanen, J., Rambal, S., Rebmann, C., Rodrigues, A., Seufert, G., Tenhunen, J., Vesala, T., and Wang, Q.: Evidence for soil water control on carbon and water dynamics in European forests during the extremely dry year: 2003, Agr. Forest Meteorol., 143, 123-145, doi:10.1016/j.agrformet.2006.12.004, 2007.

Grant, O. M., Tronina, Ł., Ramalho, J. C., Kurz Besson, C., Lobo-do-Vale, R., Santos Pereira, J., Jones, H. G., and Chaves, M. M.: The impact of drought on leaf physiology of Quercus suber L. trees: comparison of an extreme drought event with chronic rainfall reduction, J. Exp. Bot., 61, 4361-4371, doi:10.1093/jxb/erq239, 2010.

Guerreiro, S. B., Kilsby, C. G., and Serinaldi, F.: Analysis of time variation of rainfall in transnational basins in Iberia: abrupt changes or trends?, Int. J. Climatol., 34, 114-133, doi:10.1002/joc.3669, 2013.

Heimann, M. and Reichstein, M.: Terrestrial ecosystem carbon dynamics and climate feedbacks, Nature, 451, 289-292, doi:10.1038/nature06591, 2008.

Hollinger, D. Y., Kelliher, F. M., Byers, J. N., Hunt, J. E., McSeveny, T. M., and Weir, P. L.: Carbon dioxide exchange between an undisturbed old-growth temperate forest and the atmosphere, Ecology, 75, 134-150, 1994.

Hulme, M., Mitchell, J., Ingram, W., Lowe, J., Johns, T., New, M., and Viner, D.: Climate change scenarios for global impacts studies, Global Environ. Chang., 9, S3-S19, doi:10.1016/S09593780(99)00015-1, 1999.

Huxman, T. E., Wilcox, B. P., Breshears, D. D., Scott, R. L., Snyder, K. A., Small, E. E., Hultine, K., Pockman, W. T., and Jackson, R. B.: Ecohydrological implications of woody plant encroachment, Ecology, 86, 308-319, doi:10.1890/03-0583, 2005.

Ibrom, A., Dellwik, E., Larsen, S. E., and Pilegaard, K.: On the use of the Webb-Pearman-Leuning theory for closed- 
path eddy correlation measurements, Tellus B, 59, 937-946, doi:10.1111/j.1600-0889.2007.00311.x, 2007.

Johnson, F. H., Eyring, H., and Williams, R. W.: The nature of enzyme inhibitions in bacterial luminescence: Sulfanilamide, urethane, temperature and pressure, J. Cell. Compar. Physl., 20, 247-268, doi:10.1002/jcp.1030200302, 1942.

Jongen, M., Pereira, J. S., Aires, L. M. I., and Pio, C. A.: The effects of drought and timing of precipitation on the inter-annual variation in ecosystem-atmosphere exchange in a Mediterranean grassland, Agr. Forest Meteorol., 151, 595-606, doi:10.1016/j.agrformet.2011.01.008, 2011.

Jongen, M., Lecomte, X., Unger, S., Fangueiro, D., and Pereira, J. S.: Precipitation variability does not affect soil respiration and nitrogen dynamics in the understorey of a Mediterranean oak woodland, Plant Soil, 372, 235-251, doi:10.1007/s11104013-1728-7, 2013a.

Jongen, M., Lecomte, X., Unger, S., Pintó-Marijuan, M., and Pereira, J. S.: The impact of changes in the timing of precipitation on the herbaceous understorey of Mediterranean evergreen oak woodlands, Agr. Forest Meteorol., 171-172, 163-173, doi:10.1016/j.agrformet.2012.11.020, 2013b.

Jongen, M., Unger, S., Fangueiro, D., Cerasoli, S., Silva, J., and Pereira, J. S.: Resilience of montado understorey to experimental precipitation variability fails under severe natural drought, Agr. Ecosyst. Environ., 178, 18-30, doi:10.1016/j.agee.2013.06.014, 2013c.

June, T., Evans, J. R., and Farquhar, G. D.: A simple new equation for the reversible temperature dependence of photosynthetic electron transport: a study on soybean leaf, Funct. Plant Biol., 31, 275-283, doi:10.1071/FP03250, 2004.

Kattge, J. and Knorr, W.: Temperature acclimation in a biochemical model of photosynthesis: a reanalysis of data from 36 species, Plant Cell Environ., 30, 1176-1190, doi:10.1111/j.13653040.2007.01690.x, 2007.

Knorr, W.: Annual and interannual $\mathrm{CO}_{2}$ exchanges of the terrestrial biosphere: process-based simulations and uncertainties, Global Ecol. Biogeogr., 9, 225-252, doi:10.1046/j.13652699.2000.00159.x, 2000.

Kolle, O. and Rebmann, C.: EddySoft Documentation of a Software Package to Acquire and Process Eddy Covariance Data, Technical Reports 10, Max-Planck-Institut für Biogeochemie, Jena, available at: http://www.bgc-jena.mpg.de/bgc-processes/ staff/corinna.rebmann/tech_report10.pdf, 2007.

Krinner, G., Viovy, N., de Noblet-Ducoudré, N., Ogée, J., Polcher, J., Friedlingstein, P., Ciais, P., Sitch, S., and Prentice, I. C.: A dynamic global vegetation model for studies of the coupled atmosphere-biosphere system, Global Biogeochem. Cy., 19, GB1015, doi:10.1029/2003GB002199, 2005.

Krishnan, P., Meyers, T. P., Scott, R. L., Kennedy, L., and Heuer, M.: Energy exchange and evapotranspiration over two temperate semi-arid grasslands in North America, Agr. Forest Meteorol., 153, 31-44, doi:10.1016/j.agrformet.2011.09.017, 2012.

Kurz-Besson, C., Otieno, D., Lobo do Vale, R., Siegwolf, R., Schmidt, M., Herd, A., Nogueira, C., David, T., David, J., Tenhunen, J., Pereira, J., and Chaves, M.: Hydraulic lift in cork oak trees in a savannah-type Mediterranean ecosystem and its contribution to the local water balance, Plant Soil, 282, 361-378, doi:10.1007/s11104-006-0005-4, 2006.
Lasslop, G., Reichstein, M., Papale, D., Richardson, A. D., Arneth, A., Barr, A., Stoy, P., and Wohlfahrt, G.: Separation of net ecosystem exchange into assimilation and respiration using a light response curve approach: critical issues and global evaluation, Glob. Change Biol., 16, 187-208, doi:10.1111/j.13652486.2009.02041.x, 2010.

Leuning, R.: A critical appraisal of a combined stomatalphotosynthesis model for $\mathrm{C}_{3}$ plants, Plant Cell Environ., 18, 339355, doi:10.1111/j.1365-3040.1995.tb00370.x, 1995.

Leuning, R.: The correct form of the Webb, Pearman and Leuning equation for eddy fluxes of trace gases in steady and non-steady state, horizontally homogeneous flows, Bound.-Lay. Meteorol., 123, 263-267, doi:10.1007/s10546-006-9138-5, 2007.

Liu, Y., Zhou, Y., Ju, W., Wang, S., Wu, X., He, M., and Zhu, G.: Impacts of droughts on carbon sequestration by China's terrestrial ecosystems from 2000 to 2011, Biogeosciences, 11, 2583-2599, doi:10.5194/bg-11-2583-2014, 2014.

Long, S., Humphries, S., and Falkowski, P. G.: Photoinhibition of photosynthesis in nature, Ann. Rev. Plant Biol., 45, 633-662, 1994.

Ma, S., Baldocchi, D. D., Xu, L., and Hehn, T.: Inter-annual variability in carbon dioxide exchange of an oak/grass savanna and open grassland in California, Agr. Forest Meteorol., 147, 157171, doi:10.1016/j.agrformet.2007.07.008, 2007.

Matthews, M. A. and Boyer, J. S.: Acclimation of photosynthesis to low leaf water potentials, Plant Physiol., 74, 161-166, doi:10.1104/pp.74.1.161, 1984.

Mauder, M. and Foken, T.: Documentation and Instruction Manual of the Eddy-Covariance Software Package TK3, Universität Bayreuth Abt. Mikrometeorologie, available at: http://nbn-resolving.de/urn/resolver.pl?urn:nbn:de:bvb: 703-opus-8665, 2011.

Mauder, M., Cuntz, M., Drüe, C., Graf, A., Rebmann, C., Schmid, H. P., Schmidt, M., and Steinbrecher, R.: A strategy for quality and uncertainty assessment of long-term eddycovariance measurements, Agr. Forest Meteorol., 169, 122-135, doi:10.1016/j.agrformet.2012.09.006, 2013.

Medlyn, B. E., Dreyer, E., Ellsworth, D., Forstreuter, M., Harley, P. C., Kirschbaum, M. U. F., Le Roux, X., Montpied, P., Strassemeyer, J., Walcroft, A., Wang, K., and Loustau, D.: Temperature response of parameters of a biochemically based model of photosynthesis. II. A review of experimental data, Plant Cell Environ., 25, 1167-1179, doi:10.1046/j.13653040.2002.00891.x, 2002.

Miranda, P., Coelho, F., Tomé, A. R. and, V. M., Carvalho, A., Pires, C., Pires, H., Pires, V. C., and Ramalho, C.: 20th century Portuguese climate and climate scenarios, in: Climate Change in Portugal: Scenarios, Impacts and Adaptation Measures (SIAM Project), Gradiva, 23-83, 2002.

Mourato, S., Moreira, M., and Corte-Real, J.: Interannual variability of precipitation distribution patterns in Southern Portugal, Int. J. Climatol., 30, 1784-1794, doi:10.1002/joc.2021, 2010.

Nelder, J. A. and Mead, R.: A simplex method for function minimization, Comput. J., 7, 308-313, doi:10.1093/comjn1/7.4.308, 1965.

Oleson, K. W., Lawrence, D. M., Bonan, G. B., Flanner, M. G., Kluzek, E., Lawrence, P. J., Levis, S., Swenson, S. C., and Thornton, P. E.: Technical Description of version 4.0 of the Community 
Land Model (CLM)leu, Tech. rep., National Center for Atmospheric Research, 2010.

Oliveira, G., Correia, O., Martins-Loução, M., and Catarino, F.: Water relations of cork-oak (Quercus suber L.) under natural conditions, in: Quercus ilex L. Ecosystems: Function, Dynamics and Management, edited by: Romane, F., and Terradas, J., vol. 13 of Advances in vegetation science, Springer Netherlands, 199-208, doi:10.1007/978-94-017-2836-2_21, 1992.

Paco, T. A., David, T. S., Henriques, M. O., Pereira, J. S., Valente, F., Banza, J., Pereira, F. L., Pinto, C., and David, J. S.: Evapotranspiration from a Mediterranean evergreen oak savannah: the role of trees and pasture, J. Hydrol., 369, 98-106, doi:10.1016/j.jhydrol.2009.02.011, 2009.

Papale, D., Reichstein, M., Aubinet, M., Canfora, E., Bernhofer, C., Kutsch, W., Longdoz, B., Rambal, S., Valentini, R., Vesala, T., and Yakir, D.: Towards a standardized processing of Net Ecosystem Exchange measured with eddy covariance technique: algorithms and uncertainty estimation, Biogeosciences, 3, 571-583, doi:10.5194/bg-3-571-2006, 2006.

Paredes, D., Trigo, R. M., Garcia-Herrera, R., and Trigo, I. F.: Understanding precipitation changes in Iberia in early spring: weather typing and storm-tracking approaches, J. Hydrometeorol., 7, 101-113, doi:10.1175/JHM472.1, 2006.

Peñuelas, J., Filella, I., and Comas, P.: Changed plant and animal life cycles from 1952 to 2000 in the Mediterranean region, Glob. Change Biol., 8, 531-544, doi:10.1046/j.13652486.2002.00489.x, 2002.

Peñuelas, J., Filella, I., Zhang, X., Llorens, L., Ogaya, R., Lloret, F., Comas, P., Estiarte, M., and Terradas, J.: Complex spatiotemporal phenological shifts as a response to rainfall changes, New Phytol., 161, 837-846, doi:10.1111/j.1469-8137.2004.01003.x, 2004.

Peco, B. and Espigares, T.: Floristic fluctuations in annual pastures: the role of competition at the regeneration stage, J. Veg. Sci., 5, 457-462, doi:10.2307/3235971, 1994.

Pereira, J. S., Mateus, J. A., Aires, L. M., Pita, G., Pio, C., David, J. S., Andrade, V., Banza, J., David, T. S., Paço, T. A., and Rodrigues, A.: Net ecosystem carbon exchange in three contrasting Mediterranean ecosystems - the effect of drought, Biogeosciences, 4, 791-802, doi:10.5194/bg-4-791-2007, 2007.

Pérez-Ramos, I. M., Rodríguez-Calcerrada, J., Ourcival, J. M., and Rambal, S.: Quercus ilex recruitment in a drier world: a multistage demographic approach, Perspect. Plant Ecol., 15, 106-117, doi:10.1016/j.ppees.2012.12.005, 2013.

Piayda, A., Dubbert, M., Werner, C., Correia, A. V., Pereira, J. S., and Cuntz, M.: Quantifying the influence of wooden tissue and leaf clumping on vertically resolved leaf area index and angular gap probability estimates in an open savannah-type woodland, Forest Ecology and Management, submitted 2014.

Piñol, J., Lledó, M. J., and Escarré, A.: Hydrological balance of two Mediterranean forested catchments (Prades, northeast Spain), Hydrolog. Sci. J., 36, 95-107, doi:10.1080/02626669109492492, 1991.

Rebmann, C., Kolle, O., Heinesch, B., Queck, R., Ibrom, A., and Aubinet, M.: Data acquisition and flux calculations, in: Eddy Covariance: A Practical Guide to Measurement and Data Analysis, Springer, Dordrecht, 59-84, 2012.

Reichstein, M., Tenhunen, J. D., Roupsard, O., Ourcival, J.M., Rambal, S., Miglietta, F., Peressotti, A., Pecchiari, M.,
Tirone, G., and Valentini, R.: Severe drought effects on ecosystem $\mathrm{CO}_{2}$ and $\mathrm{H}_{2} \mathrm{O}$ fluxes at three Mediterranean evergreen sites: revision of current hypotheses?, Glob. Change Biol., 8, 9991017, doi:10.1046/j.1365-2486.2002.00530.x, 2002.

Reichstein, M., Tenhunen, J., Roupsard, O., Ourcival, J.-M., Rambal, S., Miglietta, F., Peressotti, A., Pecchiari, M., Tirone, G., and Valentini, R.: Inverse modeling of seasonal drought effects on canopy $\mathrm{CO}_{2} / \mathrm{H}_{2} \mathrm{O}$ exchange in three Mediterranean ecosystems, J. Geophys. Res.-Atmos., 108, 4726, doi:10.1029/2003JD003430, 2003.

Reichstein, M., Falge, E., Baldocchi, D., Papale, D., Aubinet, M., Berbigier, P., Bernhofer, C., Buchmann, N., Gilmanov, T., Granier, A., Grünwald, T., Havránková, K., Ilvesniemi, H., Janous, D., Knohl, A., Laurila, T., Lohila, A., Loustau, D., Matteucci, G., Meyers, T., Miglietta, F., Ourcival, J.-M., Pumpanen, J., Rambal, S., Rotenberg, E., Sanz, M., Tenhunen, J., Seufert, G., Vaccari, F., Vesala, T., Yakir, D., and Valentini, R.: On the separation of net ecosystem exchange into assimilation and ecosystem respiration: review and improved algorithm, Glob. Change Biol., 11, 1424-1439, doi:10.1111/j.13652486.2005.001002.x, 2005.

Rodrigues, A., Pita, G., Mateus, J., Kurz-Besson, C., Casquilho, M., Cerasoli, S., Gomes, A., and Pereira, J.: Eight years of continuous carbon fluxes measurements in a Portuguese eucalypt stand under two main events: drought and felling, Agr. Forest Meteorol., 151, 493-507, doi:10.1016/j.agrformet.2010.12.007, 2011.

Sala, A. and Tenhunen, J.: Simulations of canopy net photosynthesis and transpiration in Quercus ilex L. under the influence of seasonal drought, Agr. Forest Meteorol., 78, 203-222, doi:10.1016/0168-1923(95)02250-3, 1996.

Santos, J., Corte-real, J., and Leite, S.: Atmospheric large-scale dynamics during the 2004/2005 winter drought in Portugal, Int. J. Climatol., 27, 571-586, doi:10.1002/joc.1425, 2007.

Santos, J. A., Woollings, T., and Pinto, J. G.: Are the winters 2010 and 2012 archetypes exhibiting extreme opposite behavior of the North Atlantic jet stream?, Mon. Weather Rev., 141, 3626-3640, doi:10.1175/MWR-D-13-00024.1, 2013.

Schotanus, P., Nieuwstadt, F., and Bruin, H.: Temperature measurement with a sonic anemometer and its application to heat and moisture fluxes, Bound.-Lay. Meteorol., 26, 81-93, doi:10.1007/BF00164332, 1983.

Tenhunen, J., Lange, O., Gebel, J., Beyschlag, W., and Weber, J.: Changes in photosynthetic capacity, carboxylation efficiency, and $\mathrm{CO}_{2}$ compensation point associated with midday stomatal closure and midday depression of net $\mathrm{CO}_{2}$ exchange of leaves of Quercus suber, Planta, 162, 193-203, doi:10.1007/BF00397440, 1984.

Tenhunen, J., Lange, O., Harley, P., Beyschlag, W., and Meyer, A.: Limitations due to water stress on leaf net photosynthesis of Quercus coccifera in the Portuguese evergreen scrub, Oecologia, 67, 23-30, doi:10.1007/BF00378446, 1985.

Tenhunen, J. D., Pearcy, R. W., and Lange, O. L.: Diurnal variations in leaf conductance and gas exchange in natural environments, in: Stomatal Function, Stanford University Press, 1987.

Tenhunen, J., Serra, A., Harley, P., Dougherty, R., and Reynolds, J.: Factors influencing carbon fixation and water use by mediterranean sclerophyll shrubs during summer drought, Oecologia, 82, 381-393, doi:10.1007/BF00317487, 1990. 
Thomas, C. and Foken, T.: Re-evaluation of integral turbulence characteristics and their parameterisations, 15th Conference on Boundary Layer and Turbulence, 2002.

Trigo, R. M., Añel, J., Barriopedro, D., García-Herrera, R., Gimeno, L., Nieto, R., Castillo, R., Allen, M. R., and Massey, N.: The record winter drought of 2011-12 in the Iberian Peninsula, in: explaining extreme events of 2012 from a climate perspective, B. Am. Meteorol. Soc., 95, S41-S45, 2013.

Twine, T., Kustas, W., Norman, J., Cook, D., Houser, P., Meyers, T., Prueger, J., Starks, P., and Wesely, M.: Correcting eddycovariance flux underestimates over a grassland, Agr. Forest Meteorol., 103, 279-300, doi:10.1016/S0168-1923(00)00123-4, 2000.

Unger, S., Máguas, C., Pereira, J. S., Aires, L. M., David, T. S., and Werner, C.: Partitioning carbon fluxes in a Mediterranean oak forest to disentangle changes in ecosystem sink strength during drought, Agr. Forest Meteorol., 149, 949-961, doi:10.1016/j.agrformet.2008.11.013, 2009.

Valentini, R., Matteucci, G., Dolman, A. J., Schulze, E.-D., Rebmann, C., Moors, E. J., Granier, A., Gross, P., Jensen, N. O., Pilegaard, K., Lindroth, A., Grelle, A., Bernhofer, C., Grünwald, T., Aubinet, M., Ceulemans, R., Kowalski, A. S., Vesala, T., Rannik, U., Berbigier, P., Loustau, D., Gudmundsson, J., Thorgeirsson, H., Ibrom, A., Morgenstern, K., Clement, R., Moncrieff, J., Montagnani, L., Minerbi, S., and Jarvis, P. G.: Respiration as the main determinant of carbon balance in European forests, Nature, 404, 861-865, doi:10.1038/35009084, 2000.

Vargas, R., Sonnentag, O., Abramowitz, G., Carrara, A., Chen, J., Ciais, P., Correia, A., Keenan, T., Kobayashi, H., Ourcival, J.-M., Papale, D., Pearson, D., Pereira, J., Piao, S., Rambal, S., and Baldocchi, D.: Drought influences the accuracy of simulated ecosystem fluxes: a model-data meta-analysis for Mediterranean oak woodlands, Ecosystems, 16, 749-764, doi:10.1007/s10021-0139648-1, 2013.

Vaz, M., Pereira, J., Gazarini, L., David, T., David, J., Rodrigues, A., Maroco, J., and Chaves, M.: Drought-induced photosynthetic inhibition and autumn recovery in two Mediterranean oak species (Quercus ilex and Quercus suber), Tree Physiol., 30, 946-956, doi:10.1093/treephys/tpq044, 2010.

Verbeeck, H., Peylin, P., Bacour, C., Bonal, D., Steppe, K., and Ciais, P.: Seasonal patterns of $\mathrm{CO}_{2}$ fluxes in Amazon forests: $\mathrm{Fu}-$ sion of eddy covariance data and the ORCHIDEE model, J. Geophys. Res.-Biogeo., 116, G02018, doi:10.1029/2010JG001544, 2011.

von Caemmerer, S.: Biochemical Models of Leaf Photosynthesis, CSIRO Publishing, 2000.
Wang, Y.-P., and Leuning, R.: A two-leaf model for canopy conductance, photosynthesis and partitioning of available energy I: Model description and comparison with a multi-layered model, Agr. Forest Meteorol., 91, 89-111, doi:10.1016/S01681923(98)00061-6, 1998.

Webb, E. K., Pearman, G. I., and Leuning, R.: Correction of flux measurements for density effects due to heat and water vapour transfer, Q. J. Roy. Meteor. Soc., 106, 85-100, doi:10.1002/qj.49710644707, 1980.

Werner, C. and Correia, O.: Photoinhibition in cork-oak leaves under stress: influence of the bark-stripping on the chlorophyll fluorescence emission in Quercus suber L., Trees, 10, 288-292, doi:10.1007/BF02340774, 1996.

Werner, C. and Máguas, C.: Carbon isotope discrimination as a tracer of functional traits in a mediterranean macchia plant community, Funct. Plant Biol., 37, 467-477, doi:10.1071/FP09081, 2010.

Werner, C., Correia, O., and Beyschlag, W.: Two different strategies of Mediterranean macchia plants to avoid photoinhibitory damage by excessive radiation levels during summer drought, Acta Oecol., 20, 15-23, doi:10.1016/S1146-609X(99)80011-3, 1999.

Werner, C., Ryel, R. J., Correia, O., and Beyschlag, W.: Effects of photoinhibition on whole-plant carbon gain assessed with a photosynthesis model, Plant Cell Environ., 24, 27-40, doi:10.1046/j.1365-3040.2001.00651.x, 2001.

Werner, C., Correia, O., and Beyschlag, W.: Characteristic patterns of chronic and dynamic photoinhibition of different functional groups in a Mediterranean ecosystem, Funct. Plant Biol., 29, 999-1011, doi:10.1071/PP01143, 2002.

Wilczak, J., Oncley, S., and Stage, S.: Sonic anemometer tilt correction algorithms, Bound.-Lay. Meteorol., 99, 127-150, doi:10.1023/A:1018966204465, 2001.

Zeppel, M. J. B., Wilks, J. V., and Lewis, J. D.: Impacts of extreme precipitation and seasonal changes in precipitation on plants, Biogeosciences, 11, 3083-3093, doi:10.5194/bg-11-3083-2014, 2014.

Zhou, S., Duursma, R. A., Medlyn, B. E., Kelly, J. W., and Prentice, I. C.: How should we model plant responses to drought? An analysis of stomatal and non-stomatal responses to water stress, Agr. Forest Meteorol., 182-183, 204-214, doi:10.1016/j.agrformet.2013.05.009, 2013. 